\title{
Integrated monitoring of chemicals and their effects on four sentinel species, Limanda limanda, Platichthys flesus, Nucella lapillus and Mytilus sp, in Seine Bay: A key step towards applying biological effects to monitoring
}

\author{
Burgeot Thierry ${ }^{1,{ }^{*}}$, Akcha Farida ${ }^{1}$, Ménard Dominique ${ }^{1}$, Robinson Craig ${ }^{2}$, Loizeau Veronique ${ }^{1}$, \\ Brach-Papa Christophe ${ }^{1}$, Martínez-Gòmez Concepción ${ }^{3}$, Le Goff Jérémie ${ }^{4}$, Budzinski Hélène ${ }^{5}$, \\ Le Menach Karine ${ }^{5}$, Cachot Jerome $^{5}$, Minier Christophe ${ }^{6}$, Broeg Katja ${ }^{7}$, Hylland Ketil ${ }^{8}$
}

\footnotetext{
${ }^{1}$ Department of Biogeochemistry and Ecotoxicology, Ifremer, Rue de l'lle d'Yeu, BP 21105, 44311, Nantes cedex 03, France

${ }^{2}$ Marine Scotland Science, Marine Laboratory, 375 Victoria Road, Aberdeen, AB11 9DB, UK

${ }^{3}$ Instituto Espagňol de Oceanografia, Oceanografic Centre of Murcia, Varadero 1, 30740, San Pedro del Pinatar, Murcia, Spain

${ }^{4}$ Adn'Tox, GRECAN, Centre François Baclesse, Avenue du Général Harris, 14076, Caen Cedex 05, France

${ }^{5}$ University of Bordeaux 1, Laboratory EPOC, UMR CNRS 5805, 36615, Pessac cedex, France

${ }^{6}$ Laboratory of Ecotoxicology (LEMA), UMR SEBIO, University of Le Havre, 25 Rue P. Lebon, 76058, Le Havre, France

${ }^{7}$ Federal Maritime and Hydrographic Agency of Germany (BSH), Benhard-Nocht-Straße 78, 20359, Hamburg, Germany

${ }^{8}$ Department of Biosciences, University of Oslo, $\mathrm{Pb} 1066$, Blindern, N-0316, Oslo, Norway

*Corresponding author : Thierry Burgeot, email address : tburgeot@ifremer.fr
}

\begin{abstract}
:
The International workshop on Integrated Assessment of CONtaminants impacts on the North sea (ICON) provided a framework to validate the application of chemical and biological assessment thresholds (BACs and EACs) in the Seine Bay in France. Bioassays (oyster larval anomalies, Corophium arenarium toxicity assay and DR Calux) for sediment and biomarkers: ethoxyresorufin- $O$ deethylase (EROD) activity, acetylcholinesterase (AChE) activity, lysosomal membrane stability (LMS), DNA strand breaks using the Comet assay, DNA adducts, micronucleus (MN), PAH metabolites, imposex, intersex and fish external pathologies were analysed in four marine sentinel species (Platichthys flesus, Limanda limanda, Mytilus sp. and Nucella lapilus). Polycyclic aromatic hydrocarbons (PAHs), polychlorinated biphenyls (PCBs) and heavy metals were analysed in biota and sediment. Results for sediment and four species in 2008-2009 made it possible to quantify the impact of contaminants using thresholds (Environmental Assessment Criteria/EAC $2008: 70 \%$ and $\mathrm{EAC}_{2009}: 60 \%$ ) and effects $\left(\mathrm{EAC}_{2008}: 50 \%\right.$ and $\left.\mathrm{EAC}_{2009}: 40 \%\right)$ in the Seine estuary. The Seine estuary is ranked among Europe's most highly polluted sites.
\end{abstract}




\section{Highlights}

- Three bioassays for sediment and nine biomarkers were analysed in four sentinel species in the Seine Bay. Observed values for biological responses and contaminant concentrations were compared with BAC and EAC thresholds. This study validates BAC and EAC thresholds by demonstrating relationships on a local scale.

Keywords : Biomarkers, Bioassays, Chemical contamination, Integrated monitoring in chemistry and biology, Local study, Large geographical scale 
21 The Seine estuary is the largest megatidal estuary in the English Channel and is ranked among 22 Europe's most highly polluted estuaries in terms of chemical contamination (Carpentier et al, 232002 ; Cachot et al., 2006). The Seine estuary flows into Seine Bay,, home to the port of Le 24 Havre, one of Europe's five largest ports. $86 \%$ of the total fluvial discharge from adjacent 25 catchments in the English Channel originates from rivers along the French coasts between 26 Calais and Brest, and is dominated by the Seine and its tributaries (Millwards et al., 2015) .

27 The Seine catchment area, downstream of the cities of Paris and Rouen and upstream of Le 28 Havre, is highly urbanized and industrialized. The Seine catchment area is a hub for around $2940 \%$ of France's economic activities. It is influenced by a dense urban population (16 million 30 inhabitants), combined with extensive farming (cereals, oleaginous plants, beetroot and 31 potatoes) at around 100,000 farms. Chemical contaminant drainage to the Seine estuary, 32 combined with atmospheric inputs, represent a chronic source of contamination characterized 33 by a wide diversity of contaminants (PAHs, PCBs, heavy metals, phtalates, hormones, 34 PBDEs, EPHEs, alkyphenols, pesticides, nanoparticles, drugs), typical of large European 
cities.

This French pilot area in the Channel-North Sea OSPAR (The Oslo and Paris Convention for the Protection of the Marine Environment of the North-East Atlantic ) zone was therefore selected to validate an integrated approach of contaminants and biological effects in the framework of the ICON programme, conducted on a large geographical scale. The validation of bioassays and biomarkers currently represents a major step towards their future application to monitoring in the framework of the OSPAR Coordinated Environmental Monitoring Programme (CEMP), and of descriptor 8 "Concentrations of contaminants give no effects" of the Marine Strategy Framework Directive (MSFD). Biological effects of contaminants are widely used in many European countries to assess the impact of contaminants within an ecosystemic approach, but EU's decision-makers (EC 2008) remain to be convinced with regards to biological effect indicators. A documented reliability is key to selecting efficient biological and chemical indicators for assessing the ecological health of the marine environment and an integration method suitable for an ecosystemic approach. France drew up a legislative decree relating to the MSFD's Good Environmental Status in December 2012 (French Legislative Decree December 2012), incorporating biological and chemical indicators recommended by OSPAR. This legislative decree refers to biomarkers and bioassays (mussel and fish physiology, genotoxicity, reprotoxicity and fish pathologies) for coastal and offshore monitoring. Efforts to date have however focused mainly on coastal areas, which are far more impacted by chemical contamination than offshore areas. The legislative decree takes the biological effects of contaminants into account through a sustainable European monitoring programme, adapted to a national level. Validation of the biological effects of chemical contaminants applied to monitoring within the MSFD remains a major challenge in terms of long-term monitoring data acquisition and aggregation.

The ICON programme aims to demonstrate the pertinence of applying biomarkers and bioassays on both a wide and local geographical scale. Its strength lies in the fact that it is backed by a European consensus built on a framework developed through the International Council for the Exploration of the Sea (ICES) and OSPAR (Hylland et al., 2012 ; Hylland et al., 2016a ; Vethaak et al., 2016). Based on the numerous strategies and the different indices already proposed for biological effect data integration with specific tools as for example the multi-biomarker index (Beliaeff and Burgeot, 2002 ; Narbonne et al., 2005 ; Broeg and Lethonen 2006 ; Viarengo et al, 2007 ; Devin et al. 2013), a multistep process was proposed which follows on from experience of the assessment of contaminants data for sediment, fish and shellfish in OSPAR contexts (Vethaak et al., 2016). The main difference between the 
framework used in the ICON programme and other indices is that (1) the current framework is based on internationally agreed threshold criteria for biological responses and chemicals contamination in biota (Environmental Assessment Criteria : EAC and background assessment criteria : BAC) and (2) the framework includes more matrices than most other indices (Hylland et al., 2016a)

Appropriate sites were selected in the ICON programme from the North to the South Atlantic and one in the Mediterranean, spanning Iceland to Spain. The selection of a Mediterranean site was particularly important for France and Spain, which must harmonize monitoring efforts on the Atlantic and Mediterranean coasts. Validation at local sites would allow widescale biomarker and bioassay validation at sites with varying characteristics, from the North to the South of the North-East Atlantic and in the Mediterranean.

This paper presents the work conducted in the Seine estuary and Bay: a pilot site particularly suitable for the validation of biomarkers and bioassays and the development of an integrated chemical-biological approach in the East Channel. The Seine estuary has been the focus of research and monitoring campaigns for over 20 years (Burgeot et al., 1994 ; Minier et al., 2000 ; Burgeot and Gagné, 2013). High contaminant levels have been identified there on the basis of predominant chemical contaminants in sediment, biota and water (Chiffoleau et al., 2001 ; Gonzalez et al., 2001 ; Lafite et al., 2001 ; Le Hir et al., 2001 ; Munschy et al., 2003 ; Cachot et al., 2006). Characterized by a highly diverse fauna, but low numbers of individuals of each taxon (Tecchio et al., 2015), the Seine estuary provides a good illustration of the estuarine quality paradox (Dauvin, 2007). The parameters structuring the various organism populations, such as salinity, substrate and hydrodynamics, are extremely heterogeneous along the freshwater-estuarine-coastal-open marine continuum. The various organisms adapt their metabolism constantly to this variable environment, making it more difficult to detect impacts of other stressors in the estuarine system as a whole. This continual adaptation is nevertheless subject to annual seasonal fluctuations and, in the longer term, to global change, as a combined result of climate change and the interaction of chemical pollutants. Estuaries under continual stress are generally highly productive ecosystems and major nursery and recruitment areas for a wide variety of invertebrates and fish, which are key prey for high trophic level animals (Dauvin 2007). They hence offer a marine typology characteristic of transitional waters, with biological and physical regulation mechanisms that need to be studied and monitored. The typology of estuaries characterized by fine grain and organic-rich sediments favours a high accumulation and potential bioavailability of chemical contaminants. Estuaries are therefore priority zones for research into bioindicator species and 
the study of biomarkers and bioassays to determine the biological effects of chemical contaminants. On a legal level, monitoring of estuaries undertaken in the framework of the WFDs six-year cycles has highlighted a lack of indicators suitable for assessing the good environmental status of transitional waters in estuary zones (Boeuf and Fritsch, 2016).

A French consortium contributed to the ICON programme by conducting a sampling campaign on sediment and biota matrices in the Seine Bay, including flounder (Platichthys flesus), dab (Limanda limanda), dogwhelk (Nucella lapillus) and mussels (Mytilus sp.). The objective was to 1) validate bioassays and biomarkers in four sentinel species (flounder, dab, dogwhelk and mussels) and for sediment on a local scale in the Seine Bay and estuary 2) interpret biomarkers and bioassays according to the BAC and EAC thresholds determined per species and for sediment, 3) apply the integrated chemical and biological method developed by OSPAR (JAMP, 2012) to assess the environmental status of the Seine Bay and estuary and compare it to other selected European sites.

\section{Materials and Methods}

\subsection{Sampling}

Sampling took place at seven stations in Seine Bay (Figs 1 and 2) to collect the four selected species in a polluted area influenced by the Seine panache (Seine estuary/fish, Villerville/dogwhelk, Cap de la Hève /dogwhelk, Honfleur/mussels) around Le Havre (Figs 1 and 2) and in a zone located to the West of the Seine Bay, uninfluenced by the Seine panache (Parfond/fish, Pointe de la Loge/dogwhelk, Le Moulard/mussels). Sampling was performed in accordance with OSPAR and ICES guidelines (JAMP, 2012).

Sediment samples were collected in 2008 from the Seine estuary site on Ifremer's boat "Gwendrez", using a Shippeck grab sampler (Fig 2). The sediment was maintained at $4{ }^{\circ} \mathrm{C}$ and sent to the analysis laboratory within 48 hours.

The fish were caught in 2008 and 2009 by trawling from "Gwendrez", using a 30-minute bottom sweeps at 13 to 20 metres deep and at temperatures of around $13 \pm 2.1^{\circ} \mathrm{C}$. Just after trawling, the fish were kept alive in on-board tanks, then dissected once Gwendrez was back at berth. 10-15 individuals were sampled per station for biomarker analysis and 250 individuals were collected for fish disease. For metal, PCB and DNA adduct and PAH metabolite measurements, extra sampling was conducted to compare male and female 
sensitivity. The average size of the flounder was $29 \pm 4.2 \mathrm{~cm}$ and dab $22 \pm 5.1 \mathrm{~cm}$. The tissue, collected according to OSPAR guidelines (Davies and Vethaak, 2012, Davies et al., 2012), was stored in liquid nitrogen. Blood was taken when the fish were dissected. The blood was distributed into tubes for the comet analysis and glass slides for erythrocyte micronucleus $(\mathrm{MN})$ analyses were prepared during dissection. Tissue was packed in dry ice to be dispatched to the ICON partner laboratories.

The mussels were collected at low tide in the same week in September 2008 and 2009 by fishing on foot on natural beds at a temperature of $11 \pm 3.3^{\circ} \mathrm{C}$. The mean size of mussels was in Honfleur : $42 \pm 0.5 \mathrm{~mm}$ and Le Moulard 39 $\pm 0.6 \mathrm{~mm}$. Mussel tissue was dissected and stored in liquid nitrogen, and haemocytes were spread on glass slides for MN analysis. Mussels Mytilus sp. (mean size : 44 \pm 2.5 from the Wadden Sea were collected in accordance with the same OSCAR guidelines ( Davies et al., 2012 ; JAMP 2012). Mussels subjected to stress on stress were placed directly in air-conditioned cabinets after collection, at temperatures recommended by the OSPAR/CIEM guidelines (Davies et al., 2012). Lysosomal stability was analyzed within several hours following collection. Tissue was packed in dry ice for dispatch to the ICON partner laboratories. Mussels from the Spanish stations at Cartagena and Cape Palos were kept in cages and immersed in water at a temperature of $17^{\circ} \mathrm{C}$ (Martìnez-Gòmez et al., 2016). In Spain, mussels were collected in Malaga (SE Spain) in mid september 2008 and were transplanted for a period of seven weeks to two coastal sites, Cartagena and Cape Palos (SE Spain) (Fig1) as described by Martìnez-Gòmez et al., 2006). This group of mussels were adults of standard shell size $45 \pm 0.5 \mathrm{~mm}$. The depth of the stations was 20-30 m and a buoy attached to the upper part of the mussel bag maintained in at a depth of 6-8 $\mathrm{m}$ from the surface. Samples were recorded in November 2008 and transported to the IOE laboratory in Murcia before analysis. All the tissues were stored in liquid nitrogen as recommended by the Ospar guidelines (JAMP, 2012 ; Davies and Vethaak, 2012) and transmitted in the French laboratory of Ifremer for AChE analysis.

The dogwhelks were collected in April 2008 and 2009 for analysis of VDSI in the framework of the French national network for the observation of chemical contamination (ROCCH).

\subsection{Bioassays on sediment}

The embryotoxicity test on Crassostrea gigas flat oyster larvae is advocated by the ICES using the method described in Thain (1991) and recommendations in Davies and Vethaak, 
2012. The test sediment was homogenized manually and passed through a 2-mm nylon sieve. It was then diluted in synthetic seawater and the suspensions obtained can be used directly for larval development. Fertilized eggs obtained from mature oysters (or mussels) were rapidly distributed in the test environment. The oyster larva develops at a temperature of $24^{\circ} \mathrm{C}$ for 24 hours (48 hours at $20^{\circ} \mathrm{C}$ for mussels). After stopping incubation, the larvae were counted under a microscope. Larvae quality was ranked into two categories: normal and abnormal larvae (mantels partially protruding from shells, malformed shells, abnormal segmentation sizes). The toxic dose required to obtain 50\% abnormal larvae (CI-50) was then determined. Test conditions were controlled using a reference contaminant $\left(\mathrm{Cu}^{2+}\right)$. The sediment toxicity test on Corophium arenarium was performed using the method described by Roddie and Thain (2001), as reported in Davies and Vethaak (2012). This test consists of placing adult amphipods in contact with sediment or its dilutions in order to determine the concentration incurring death of $50 \%$ of individuals. Corophium arenarium were collected from the natural environment along with reference sediment for the dilutions. The test sediment was placed in layers of at least $15 \mathrm{~mm}$ at the bottom of the grab samplers. Seawater equivalent to at least 5 times the height of the sediment was then added. After a stabulation and test condition control period, 20 animals per replicate were introduced into the samplers. The static test with airing lasted 10 days at $15^{\circ} \mathrm{C}$ under constant lighting. CE20 and CE50 were calculated at the end of the test after counting dead and living animals. Each test series was accompanied by a reference test $\left(\mathrm{Cd}^{2+}\right)$ in order to check the test conditions and sensitivity of the Corophiums $\mathrm{sp}$ used. The net percentage of dead Corophiums in undiluted sediment was also determined.

The DR-CALUX in vitro test, for determining the dioxine-like potential of sediment organic extracts, was performed using the protocol described by Murk et al. (1996) and modified by Thain et al. (2006). The sediment extracts (concentrated 50x) were added at cell mid-exposure time using $0.4 \%$ DMSO over a range of dilutions (1/1 to 1/3000th). Test samples were $10.5 \mathrm{~g}$ sediment with a resuspension volume of $200 \mu \mathrm{L}$ DMSO. In vitro toxicity tests were performed on sediment extracts collected in September 2008 and 2009 in the Seine estuary, in 2008 from the Wadden Sea (Fig. 1) and in 2009 in Iceland (IS2). The sediment was frozen at $20^{\circ} \mathrm{C}$ prior to laboratory analysis. Dioxin-like activity was determined after $24-\mathrm{hr}$ cell exposure to sediment organic extracts. Activity was expressed in pg Toxic Equivalents (2,3,7,8-tetrachlorodibenzo- $p$-dioxin; 2,3,7,8-CDD) TEQ $\mathrm{g}^{-1}$ of dry sediment (pg TEQ $\mathrm{g}^{-1}$ dry wt). 
A battery of biomarkers was selected among the core biomarkers recommended by Davies and Vethaak, 2012 to assess to exposure status (EROD, AChE and PAH metabolites) and the biological effects (LMS, MN, DNA adducts, Comet, Pathologies, imposex, stress on stress (SOS) of chemical contaminants on flounder, dab, dogwhelks and mussels. The selected biomarkers satisfied the following monitoring criteria of the JAMP 2012 : (1) reference method, (2) quality assurance and (3) BAC/EAC thresholds. They provided information on a spectrum of molecular, cellular and tissue biological response mechanisms in fish, mussels and the dogwhelk. Lysosomal stability (LMS), ethoxyresorufin-O-deethylase (EROD), PAH metabolites, comet, DNA adducts, micronucleus (MN), acetylcholinesterase (AChE) and external pathologies were assessed in flounder and/or dab. AChE, LMS and stress on stress (SOS) were assessed in mussels and imposex in dogwhelks.

The biomarkers were analyzed using the reference methods described by the CIEM and reported by Davies and Vethaak, 2012. EROD (ethoxyresorufin- $O$-deethylase) enzyme activity was measured in fish liver using the method published by the CIEM (Stagg and McIntosh, 1998). Acetylcholinesterase (AChE) enzyme activity was determined in fish muscle and in mussel gills according to the method described by Bocquené and Galgani, 1998. Lysosomal stability (LMS) was measured in the hepatic cells (histochemical approach) of dab (Broeg and Gorbi, 2011) and in the haemocytes of mussels, according to the ( NRR) method published by ICES (Moore et al., 2004). Stress on stress was measured in mussels as described by Martìnez-Gòmez et al., (2012). Micronucleus (MN) analyses were conducted on the haemocytes of mussels according to Baršiene et al. (2006). The comet assay was performed on erythrocytes of flounder according to the method of Akcha et al. (2003). PAH metabolites were measured in bile using the methods of Mazéas and Budzinski (2005). DNA adducts in flounder and dab liver were measured using the method described by Lyon and Davies (2012). Flounder intersex was assessed using method described by Stentiford et al. (2012). Vitellogenin was analysed in the plasma of Platichthys flesus according to Scott and Hylland (2002). Fish external pathology analyses were conducted as a complement to the work of Lang et al, (2016), and using the method published by Feist et al. (2004).

234 Imposex analysis on Nucella lapilus dogwhelk populations was conducted in the framework of the French national observation network, according to the guidelines recommended by 
OSPAR (Gubbins et al., 2012). Imposex is the first compulsory biomarker used to assess biological effects within an OSPAR/ICES coordinated environmental monitoring programme (CEMP). A six-class scheme (A-F) was devised for dogwhelk populations on the basis of the vas deferens sequence index (VDSI), relating to relevant concentrations of TBT (close to zero and at EAC) and effects (reduced growth, recruitment, sterility and health).

\subsection{Chemical contamination}

Chemical analyses in sediment, dab and flounder collected in 2008 were performed with the help of the Marine Scotland Science Marine Laboratory. Analysis methods are described by Robinson et al., 2016. French data on chemical contamination in sediment and mussels was provided by the French National Observation Network (ROCCH). Metal analysis methods for flounder and dab sampled in 2009 were applied according to the modified method of Chiffoleau et al. (2001) and Idardare et al. (2008). Collected mussels in September 20082009 on natural beds were frozen and transported to the laboratory where they were shelled. The mussel tissue was ground then freeze-dried. The fish caught from "Gwendrez" were dissected then frozen at $-18^{\circ} \mathrm{C}$ on board, before being ground and freeze-dried at the laboratory. Aliquots of freeze-dried samples $(150-200 \mathrm{mg})$ were digested with $\mathrm{HNO}_{3} / \mathrm{HCl}$ in a microwave oven (MARS-5, CEM Corporation) equipped with a carousel holding 12 Teflon vessels and under temperature and pressure control. After cooling, the digests were diluted to $50 \mathrm{~mL}$ with $\mathrm{mQ}$ water.

The digests were then analyzed by ICP-Q-MS (Element $\mathrm{X}$ series, Thermo Electron Corporation) using external calibration. Internal standards $115 \mathrm{In}$ or $103 \mathrm{Rh}$ were systematically added to all solutions submitted to the analysis to compensate instrumental drift and matrix effects. The results were validated using certified reference materials (CRMs) included with each batch sample. The values obtained were systematically within the range of certified values. The quantification limits $\left(\mathrm{QL}: \mu \mathrm{g} \cdot \mathrm{g}^{-1}\right)$ of the various compounds were $\mathrm{Hg}$ : $0.015 ; \mathrm{Pb}, \mathrm{Cd}, \mathrm{Ag}, \mathrm{Zn}: 0.05, \mathrm{Zn}: 25 ; \mathrm{Cu}: 2.5, \mathrm{Ni}: 0.25$

PCB analyses in sediment, dab and flounder in 2008 were performed by the method of Robinson et al. (2016). The analysis of PCBs and total lipids in flounder and dab tissue in 2009 was performed according to the methods described Bodiguel et al. (2009). This protocol features several stages: freeze-drying, solvent extraction (Soxhlet type), acid purification and florisil column. Quantification was performed using a gas chromatograph fitted with electron 


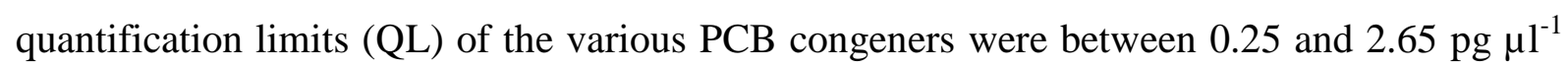
injected. The methods were implemented in compliance with strict quality assurance procedures: analysis of replicates, blanks and certified samples.

Seventeen PCB congeners were tested, i.e. the compounds CB-31, -28, -52, -101, -105, -110, $\mathbf{- 1 1 8},-128,-132,-\mathbf{1 3 8},-149,-\mathbf{1 5 3},-156,-170,-180,-187$ and -194 . These included the 7 PCB (Sum 7 CBs) contamination marker compounds (Table 4), to which were added 3 dioxin-like mono-ortho-substituted compounds (CB-105, CB-118 and CB-156).

\subsection{An integrated assessment framework for contaminants and biological effects}

This work relates to the integrated chemical and biological approach developed by a consortium of ICES experts working within a special group (SGIMC, 2011) and published in a collective report (Davies \& Vethaak, 2012). This approach, developed on the basis of OSPAR/ICES field data, satisfies legal requirements for data integration and aggregation in the MSFD framework. It incorporates contaminant and biological effect monitoring data and allows assessments to be made across matrices, sites and regions, together with multiple levels of aggregation for different assessment requirements. It was successfully used to obtain a wide range of contaminant data for the OSPAR QSR 2010 (OSPAR commission 2009) and can be extended to include the measurement of other chemical and biological effects, through the application of a coherent set of assessment criteria (EAC and BAC) (Tables 2,3 and 4). The assessment criteria used as a thresholds chemical components and biological effects of the chemical contaminants were OSPAR Background Assessment Criteria (BACs) and Environmental Assessment Criteria (EACs) (Hylland et al., 2016a). The approach involves a 5-step process and was described in the Hylland et al., 2016a). It could be also suitable for GES assessment as required by descriptor 8 of the MSFD ("Concentrations of contaminants are at levels not giving rise to pollution effects").

\subsection{Statistical analysis}

299 Statistical analyses were performed using Statistica software. The non-parametric Kruskal300 Wallis one way analysis of variance on ranks with the Nemenyi post-hoc test has been applied 301 for biomarkers and bioassays. The significance level was $\mathrm{P}<0.05$. 
As the distribution of ADN adduct concentrations per pool is not Gaussian, parametric tests such as ANOVA could not be used efficiently. Subject to exception, all results were processed using non-parametric statistics (Fisher exact, Wilcoxon, Kruskal Wallis tests). Data transformation into logarithms $\left(\log _{10}\right)$ enabled standardization of non-null data distribution and authorized recourse to parametric statistics for truncated data. An analysis was also performed taking into account the presence or absence of adducts in each pool (adduct "presence/absence" qualitative analysis). This semi-quantitative technique is particularly useful in case of low adduct concentration measurements.

The variability of biomarkers was considered to classify them into three colored bare scale. The confidence intervals and the probability of membership in each of the classes (WFD CIS guidance document $\left.n^{\circ} 13,2005\right)$ were obtained by using the sampling Bootsrap statistic method (Davison and Hinkley, 1997 ; Chernik, 2007).

\section{Results}

\subsection{Sediment bioassays}

Application of the BAC 20\% and EAC 40\% thresholds (Table 1) given in Davies and Vethaak (2012) for anomalies in Crassostrea gigas oyster larvae exposed to 5 g.L $\mathrm{L}^{-1}$ dry sediment allowed us to classify sediment collected from the Seine estuary adjacent to Le Havre and under the direct influence of the Seine panache (Fig. 2). The results obtained were compared to two other ICON European sites in the North Atlantic (Wadden Sea) and Mediterranean (Cartagena) (Table 2).

In 2008, oyster embryo-larval assay applied in sediments from the Seine estuary showed a high toxic potential (54\%). Sediments from the Wadden Sea in the Netherlands were characterized by an even higher potential toxicity (99\%), way above the EAC $40 \%$. The Spanish sediment samples collected from Cartagena showed 34\% toxicity and were hence 330 classified as having average toxicity, between BAC (20\%) and EAC (40\%). In 2009, sediment 331 from Iceland showed a low toxicity of 5.4\%, hence < BAC $(20 \%)$. The embryotoxicity test 332 confirmed the high toxicity of sediment and enabled classification of the toxic potential of 
sediment from the Seine estuary by comparison with the highly-toxic sediment found in the Wadden Sea and North Sea, and averagely-toxic sediment found in the Mediterranean.

Sediment toxicity can be partially interpreted according to the physico-chemical parameters of sediment, which is coarser in the Seine estuary $(\%<20 \mu \mathrm{m}: 19.4$ and $\%<63 \mu \mathrm{m}: 49)$ than at the Wadden Sea station $(\%<20 \mu \mathrm{m}: 24.5$ and $\%<63 \mu \mathrm{m}: 64.0)$ - a foreshore area comprising $24.5 \%$ sandy mud and 64\% clay and silt mud - and Cartagena station, located in the hottest area (temperature: $17^{\circ} \mathrm{C}$; Martìnez-Gòmez et al., 2016), containing ( $\%<20 \mu \mathrm{m}: 33.7$ and $\%<63 \mu \mathrm{m}: 59.2) 34 \%$ sandy mud and 59\% clay and silt mud (Robinson et al., 2016). The Iceland station (IS2), located further offshore than the others stations and in a colder region ( Robinson et al., 2016), is characterized by sediment with an even coarser grain size $(\%<20 \mu \mathrm{m}: 17.3$ and $\%<63 \mu \mathrm{m}: 28.2)$ than the Seine. This may lead to a lower bioavailability of chemical contaminants in coarser grain size (Vethaak et al., 2016) when oyster larvae are exposed during bioassays. A classification of the four sediment types per granulometry and mud levels (clay and silt) gave the following: Iceland (IS2)<Seine estuary $<$ Cartagena $<$ Wadden Sea. As indicated by Robinson et al. (2016) and Vethaak et al. (2016), sediment profiles differed between the Wadden Sea and Cartagena versus the Seine estuary and were different again offshore of Iceland.

Total Organic Carbon (TOC) measurements confirmed clearly higher levels of organic matter in the Wadden Sea (2.9\% TOC) versus Cartagena (0.87\% TOC) and Iceland (0.78\% TOC). The Seine estuary stands out with $1.30 \%$ TOC. Cartagena $(0.87 \%$ TOC) and Iceland (IS2) $(0.78 \%$ TOC), were similar. The Seine estuary appears to occupy an intermediate position between the Wadden Sea and Cartagena on the one hand, and Iceland on the other. Sediment chemical contamination levels nevertheless pinpointed Wadden Sea as the most highlycontaminated site with regards to the PAHs (fluoranthene : $67 \mu \mathrm{g} \cdot \mathrm{kg}^{-1}$ d.w., benzo(a)pyerene : $32 \mu \mathrm{g} . \mathrm{kg}^{-1}$ d.w , pyrene : $48 \mu \mathrm{g} . \mathrm{kg}^{-1}$ d.w. and CB153 : $1.1 \mu \mathrm{g} . \mathrm{kg}^{-1}$ d.w.) (Robinson et al., 2016). The Cartagena site showed the highest heavy metal contamination with regards to lead and zinc (Robinson et al. (2016) ; lead : $131 \mu \mathrm{g} . \mathrm{kg}^{-1}$ d.w. and zinc : $184 \mu \mathrm{g} . \mathrm{kg}^{-1}$ d.w.). In comparison, the Seine estuary showed intermediate contamination, with a highly-diversified chemical spectrum and, in particular, high concentrations of benzo(a)pyrene (14.5 $\mu \mathrm{g} . \mathrm{kg}^{-1}$ d.w) and fluoranthene (23.3 $\mu \mathrm{g} \cdot \mathrm{kg}^{-1}$ d.w), benzofuoranthene $\left(38.3 \mu \mathrm{g} \cdot \mathrm{kg}^{-1} \mathrm{~d} . \mathrm{w}\right)$ (Table 3).

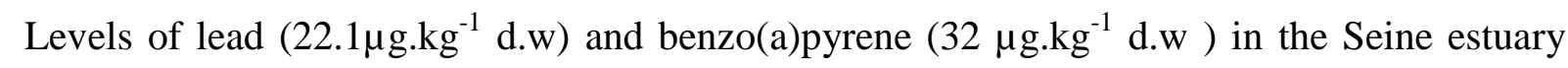
were far lower than in the Wadden Sea and Cartagena. The Iceland site showed far lower chemical concentrations, e.g. for lead : $2.9 \mu \mathrm{g} . \mathrm{kg}^{-1}$ d.w (Robinson et al., 2016). A global interpretation of the Seine estuary's typology revealed high contamination with fine sediment 
comprising 50\% clay and silt, but a coarser grain than at the Wadden Sea and Cartagena sites. The Seine estuary, which is also situated at an intermediate latitude and temperature versus the Wadden Sea in the North and Cartagena in the South, therefore offers characteristic sediment typology and high chemical contamination (Amiard and Rainbow, 2009).

The DR-CALUX bioassay (Table 2) quantified very high dioxine-like activity in sediment collected from the Seine in 2008 and 2009 (3050 \pm 1626 pg TEQ g $^{-1}$ dry wt) with values exceeding the maximum allowable concentration (dry weight) in heavily dioxin-contaminated sediment sites in Vietnam (150 pg TEQg ${ }^{-1}$ dry wt) (Hatfield Consultants 2009 in Davies and Vethaak, 2012) by a factor of 13 (2008) to 20 (2009). The DR-CALUX is a highly sensitive and reproducible bioassay that can usefully complement standard PCB analysis. Using a European site in Holland for comparison, the target value was set at 50 pg TEQ g ${ }^{-1}$ dry wt. The values obtained in the Seine estuary were in the upper range of the values observed by Vethaak et al. (2016) : between 20 and 3493 pg TEQg $^{-1}$ dry wt. No activity of this type was detected in the sediment from the Iceland offshore station, located in the coldest and least contaminant-exposed geographical area. All three 3 sediments revealed H4IIE cytotoxicity at the highest tested concentrations (Table 2).

The bioassays on Corophium arenarium quantified the net percentage of dead Corophium in undiluted sediment (\% Corophium in sediment - \% test Corophium) (Table 2) at $12.4 \%$ in the Wadden Sea and $10.7 \%$ at Cartagena. Nevertheless, if we refer to the USEPA 1998 recommendations, which classify sediment toxicity as a net percentage of $20 \%$ or above, the sediment cannot be considered as toxic. The low sediment toxicity revealed by the Corophium test can also be confirmed by applying the $\mathrm{CE}_{20}$ threshold, which was never reached by the four sediments $\left(\mathrm{CE}_{20}\right.$ : \% > 100). Application of the EAC (60) and BAC (30) thresholds therefore confirmed a low toxic potential detected by Corophium exposure to the four test sediments, but similar physico-chemical properties were found in the Wadden Sea and Cartagena, while the Seine estuary and Iceland showed levels over two times lower.

\subsection{Chemical contamination of sediment, mussels, flounder and dab}

The chemical contamination of sediment, fish and mussels in 2008 was described in the manuscript by Robinson et al. (2016). The Seine estuary was singled out as having a major 
PAH source, of pyrolitic origin, with concentrations in sediment exceeding the ERL (Tab 4) (Cachot et al., 2006). The results obtained by Cachot et al. (2006) in the sediment sampled in the two costal stations in Le Havre (Fluoranthene : $253 \mu \mathrm{g} . \mathrm{kg}^{-1}$ d.w ; pyrene $215 \mu \mathrm{g} . \mathrm{kg}^{-1}$ d.w) and in Villerville (Fluoranthene : $286 \mu \mathrm{g} \cdot \mathrm{kg}^{-1} \mathrm{~d} . \mathrm{w}$; pyrene $236 \mu \mathrm{g} \cdot \mathrm{kg}^{-1} \mathrm{~d} . \mathrm{w}$ ) were more elevated than the ICON station (Seine estuary) located in the mouth of the Seine river (Fluoranthene : $23.3 \mu \mathrm{g} . \mathrm{kg}^{-1}$ d.w ; pyrene $19.4 \mu \mathrm{g} . \mathrm{kg}^{-1}$ d.w) (Table 4). Fluoranthene (2008 : $25.4 \mu \mathrm{g} . \mathrm{kg}^{-1}$ d.w and $2009: 19.2 \mu \mathrm{g} . \mathrm{kg}^{-1}$ d.w ), benzo[a]pyrene ( $2008: 11.7 \mu \mathrm{g} \cdot \mathrm{kg}^{-1}$ d.w. and 2009 : $7.8 \mu \mathrm{g} . \mathrm{kg}^{-1}$ d.w) and pyrene ( $2008: 31.8 \mu \mathrm{g} . \mathrm{kg}^{-1}$ d.w. and $2009: 19.6 \mu \mathrm{g} . \mathrm{kg}^{-1}$ d.w. ) concentrations in the Seine estuary were elevated after the highly-contaminated site in the Forth estuary-Blackness station (Robinson et al., 2016).

Mussel contamination showed a similar profile to that of sediment (Rocher et al., 2006). The Le Moulard site (Fig 2) in the western area of Seine Bay was shown to be contaminated by metals in mussel tissue, despite being far from the estuary and outside the influence of the Seine plume, which is the main source of chemical contaminants in Seine Bay. PCBs contents were in mussels from the Seine estuary ranged between moderate and high contaminated areas of different bays worldwide (Rocher et al., 2006). In this study, the Seine estuary were particularly characterized by far higher PCB levels than those found at the other ICON programme study sites ( A factor 5 can be used for conversion from dry weight to wet weight : d.w /5= w.w), with CB 153 equal to $\left(184 \mu \mathrm{g} \cdot \mathrm{kg}^{-1}\right.$ d.w. $)$ and a sum of the seven CBs equal to $484 \mu \mathrm{g} \cdot \mathrm{kg}^{-1}$ d.w. (Table 3). Mussel contamination by lead, cadmium and mercury in the Seine estuary (Tab 4) was very similar to that found in the Wadden Sea (Robinson et al.,2016). Although not influenced by the Seine plume, mussels from Le Moulard were found to be particularly contaminated by cadmium, as was sediment. Le Moulard is less contaminated by a diffuse contamination than the Seine estuary but the oyster embryotoxicity of organic extracts from sediments sampled in 2003 was similarly demonstrated in Le Havre and Le Moulard (Cachot et al., 2006). A study of the genotoxicant accumulation was also investigated in Le Moulard and the blue mussels collected in 2003 were shown to contain extremely high DNA adduct levels (Rocher et al., 2006). Only limited number of genotixicants were measured and lot of other toxicants than xenobiotics, phycotoxins or even radionuclei are currently present in this area.

430 Chemical contamination of flounder and dab by PCBs and metals was analyzed in the muscles of pools of ten individuals. CB153 was the main compound found in both species 
characterized by the presence of CBs with 5 to 7 chlorine atoms, typical of contamination of benthic origin, or relatively-old contamination, as the least-chlorinated compounds are less persistent in the environment. Flounder and dab nevertheless differ in that dab have a higher muscle lipid content. Flounder from the Seine estuary showed higher contamination levels in 2008 in both sexes. A factor 6.5 was observed between flounder caught in 2008 and 2009 (Tab 4), underlining the high variability of bioaccumulation in fish. The migration by flounder within the upper estuary and Seine Bay is one possible explanation for these high variations in contaminant concentrations (Nahklé et al., 2007). Few differences are detected with CBs in dab between 2008 and 2009. Measured values of CB28, CB52, CB101, CB 105, CB118, CB138, CB153, CB156 and CB180 in dab and flounder were all higher than BAC (Table 4) but lower than EAC. The expression of CB concentrations per gram of lipids revealed higher levels in flounder. Metal levels measured in 2008-2009 showed very similar levels in both flounder and dab fished at the Parfond and Seine estuary stations (Table 3). Cadmium, mercury and lead measurements were all less than $1 \mathrm{mg} \cdot \mathrm{kg}^{-1} \mathrm{~d} . \mathrm{w}$. and therefore far lower than BAC (Cd : 26 mg.kg ${ }^{-1}$ d.w. ; Hg : 35 mg.kg ${ }^{-1}$ d.w.; Pb : 26 mg.kg ${ }^{-1}$ d.w.). Nevertheless, the concentration of $\mathrm{Hg}$ analysed in flounder was higher than the average concentration of $\mathrm{Hg}$ in the Seine Bay (0.25 mg.kg-1 d.w.) (Nahklé et al., 2007)

\subsection{Biomarker responses}

Biomarkers were interpreted by applying the EACs and BACs measured in the Seine Bay to all seven stations, then comparing them to other ICON programme sites (EC 2008, OSPAR, 2009, Davies \& Vethaak, 2012). Some biomarker results were available for fish from the Seine estuary and Parfond with regards to LMS (Broeg et al, 2016) and PAH metabolites (Kamman et al., 2016) and for mussels regarding stress on stress and LMS (Martìnez- Gòmez et al., 2016).

In fish, EROD enzyme activity measured in dab was below BAC (147 pmol.min ${ }^{-1} . \mathrm{mg}$ proteins $^{-1}$ ) at both the Parfond and the Seine estuary stations. For flounder, EROD activity (28 pmol. $\mathrm{min}^{-1} . \mathrm{mg}$ proteins ${ }^{-1}$ ) was very slightly higher than BAC (24 pmol. $\mathrm{min}^{-1} \cdot \mathrm{mg}$ proteins ${ }^{-}$ $\left.{ }^{1}\right)$ at the Seine estuary station and lower than BAC at the Parfond station (Table 3). In the Seine Bay, the Seine estuary station showed the lowest AChE activity analysed in dab in 2008

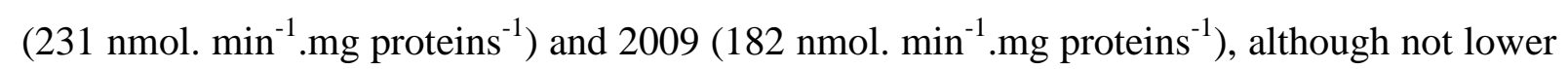
than BAC (150 nmol. min $^{-1} . \mathrm{mg}$ proteins $\left.{ }^{-1}\right)$. In flounder, AChE activity measured in 2008 (185 nmol. $\mathrm{min}^{-1} \cdot \mathrm{mg}$ proteins $\left.{ }^{-1}\right)$ and $2009\left(225\right.$ nmol. $\mathrm{min}^{-1} \cdot \mathrm{mg}$ proteins $\left.{ }^{-1}\right)$ was shown to be lower 
than BAC (235 nmol. min $^{-1} . \mathrm{mg}$ proteins $\left.{ }^{-1}\right)$ in the Seine estuary. Significantly decreased LMS was assessed in dab from the Seine estuary compared to dab from Iceland (Broeg et al.,2016). The LMS value in dab was lower than EAC (10 min) (Table 3).

PAH metabolite distribution in flounder and dab was dominated (Tables 3 and 5) by 1-OHPyrene, which was present above the detection limit in most samples (between 60 and over $80 \%)$. OH-BaPs, when they could be detected and quantified, were also relatively abundant (Table 5). Conversely, di- and tri-aromatic PAH metabolites were largely under-represented. This reveals a predominantly pyrolitic footprint at the study sites (Rocher et al., 2006 ; Robinson et al., 2016). high percentage of light compounds, suggesting a considerable additional petrogenic input (OHPyr/OHPhen ratio close to 3 versus 20 to 60 for the other sites (Kammann et al., 2016). A comparison of the various ICON sites in 2008 showed the Alde river in the UK to be the most-contaminated site, followed by the Seine estuary (Kammann et al., 2016). The Seine estuary therefore appears to be highly-contaminated by PAHs and relatively more impacted with the $\mathrm{OH}-\mathrm{BaP}$ metabolite than the other sites $(30 \%)$. No significant difference was noted across species in the Seine, although dab did appear to be a little more contaminated with $\mathrm{OH}-\mathrm{Pyr}\left(\mathrm{OH}-\mathrm{Pyr}\right.$ of flounder liver $348 \pm 183 \mathrm{ng} \cdot \mathrm{g}^{-1}$ and $\mathrm{OH}-\mathrm{Pyr}$ of dab liver 534 $\pm 305 \mathrm{ng} \cdot \mathrm{g}^{-1}$ ). Dab was the only species with detectable 3-OH-Flu in two females only (49 and $160 \mathrm{ng} \cdot \mathrm{g}^{-1}$ ). In the other two species, PAH metabolite levels measured in 2009 in the Seine estuary were lower than in 2008. The factor of 10 separating the two years confirms inter-annual variations. Among the environmental factors likely to influence PAH exposure and hence metabolism, the Seine flow measured in the upper stream at Poses in September 2009 was weaker $\left(180 \mathrm{~m}^{3} \cdot \mathrm{s}^{-1}\right)$ than in September $2008\left(340 \mathrm{~m}^{3} \cdot \mathrm{s}^{-1}\right)$ (Millwards et al., 2015)

On a quantitative level, the analysis of DNA adducts were achieved in liver and per pool in 2008-2009. The analysis showed adduct concentrations of between $0.3 \pm 0.3 \mathrm{nmol}$ adduct.mol DNA $^{-1}$ and 2.7 nmol adduct.mol DNA ${ }^{-1}$ (Table 3), (BAC : 1 nmol adduct.mol DNA ${ }^{-1}$ and EAC : 6 nmol adduct.mol DNA ${ }^{-1}$ ). Wide disparities in adduct concentrations were observed across sites (Seine Estuary in dab: $0.3 \pm 0.3$ versus dab at Parfond : $2.7 \pm 3.3 \mathrm{nmol}$ adduct.mol DNA ${ }^{-1}$ ) but also sometimes within the same site (e.g. DNA adducts measured in pools of "Seine estuary" female dabs (2009) between 0.7 and 10.9 nmol adduct.mol DNA ${ }^{-1}$ ). At least one positive result was obtained at each of the study sites in 2008 and 2009. Differences were observed between dab and flounder. DNA adducts in dab were higher at Parfond $\left(2.7 \pm 3.3\right.$ nmol adduct.mol $\mathrm{DNA}^{-1}$ than in the Seine estuary $(0.3 \pm 0.3 \mathrm{nmol}$ adduct.mol $\left.\mathrm{DNA}^{-1}\right)(\mathrm{p}=0.05)$. Conversely, DNA adducts in flounder were similar in the 
Seine estuary $\left(1.3 \pm 1.1 \mathrm{nmol}\right.$ adduct.mol $\left.\mathrm{DNA}^{-1}\right)$ and at Parfond $(0.7 \pm 0.6 \mathrm{nmol}$ adduct.mol

$502 \mathrm{DNA}^{-1}$ ).

503 The Comet test was performed on flounder from Parfond and the Seine estuary. No 504 significant difference was detected between the two stations (Table 3). However, comet 505 analysed in flounder (Seine estuary/2008 : $10 \pm 6.3 \%$ DNA Tail ; Parfond/2008 : $8.2 \pm 6.9 \%$ 506 DNA Tail and Seine estuary/ $2009: 15.5 \pm 10.5 \%$ DNA Tail ; Parfond/2009 : $12.7 \pm 9.3 \%$ 507 DNA Tail) were higher than BAC (5 \% DNA Tail).

$508 \mathrm{MN}$ analysis in the same flounder and dab from the Parfond and Seine estuary stations 509 revealed no significant differences. A high variability was found in micronuclei; as a result, 510 no differences could be highlighted between species or stations in 2008 and 2009. The MN 511 values observed in dab were similar to BAC (0.5 MN.1000 cells $\left.{ }^{-1}\right)$ in 2008 and higher than 512 BAC in 2009 in the Seine estuary and at Parfond (Table 3). MN values in flounder were 513 higher than BAC (0.3 MN.1000 cells $\left.{ }^{-1}\right)$ in 2008 and 2009 in the Seine estuary .

514 Regarding intersex, a histological analysis of flounder gonads quantified $5.5 \%$ intersexed 515 flounders in the Seine estuary in 2008. Although this was slightly lower than the data 516 available from 1997-1998 (then 8\% ; Minier et al., 2000), these values remain high and slightly above BAC (5\%), but lower than EAC (20\%).

518 Observations on external and internal pathologies in flounder and dab were conducted in the 519 Seine estuary in 2008 and 2009. They were no systematic monitoring fish disease along the 520 French Atlantic coast except some few studies on histopathological lesions in Platichthys 521 flesus (Cachot et al., 2013 ) in the Seine estuary. Identified external pathologies were skin and 522 fin necroses, as well as belly hyperpigmentation and the presence of parasites. Only two indicators of the fish disease index (FDI) (Lang and Wosniok, 2008) were observed in dab and flounder in the Seine Bay: healing skin ulcerations (UI: aetiology with bacterial involvement) and hyperpigmentation (Hp: aetiology still unresolved). The prevalence of healing skin ulcerations ranged from $0.2-1.6 \%$ in flounder to $0.3-2.7 \%$ in dab. These figures were similar to those found at most ICON stations, but lower than the highest value $(7 \%)$ in

528 Iceland (IS2) (Lang et al., 2016). Hyperpigmentation showed a similar prevalence in the Seine 529 Bay in flounder (0.2-2.4\%) and dab (0.3-3.9\%), comparable to the German Bight (5\%) but 530 lower than Dogger bank (40\%) (Lang et al., 2016). 0.8\% of hepatic nodules in 2008 and $1.7 \%$ 531 in 2009 were identified in dab sampled in the Seine estuary . $90 \%$ of flounders were infected 532 with parasitic copepoda and $47 \%$ were infested with gill parasites.

533 Stress on stress (SOS) in mussels (Martìnez-Gómez et al., 2016) revealed the resistance time 534 of mussels from Honfleur (Fig. 2) to be significantly lower versus mussels from Moulard. 
Median resistance time was 8 days in Le Havre versus 13 days in Le Moulard. Honfleur mussels, directly influenced by inputs from the Seine, had the following SOS classification: EAC (5) $<$ SOS $<$ BAC (10).

AChE interannual variability was revealed in the Seine estuary in Mytilus sp mussel samples collected from Honfleur in 2008 and 2009 (Table 6). In 2008, caged Mytilus galloprovincialis mussels were collected from Cape Palos in Cartagena (SE Spain) (Martìnez-Gómez et al, 2016) and Mytilus sp. samples were taken from natural beds at Honfleur and Wadden sea. The mussels from the Honfleur site were characterized by more inhibited AChE activity than at the other sites $\left(43 \pm 15 \mathrm{nmol} \cdot \mathrm{min}^{-1} \cdot \mathrm{mgprot}^{-1}\right)$. AChE activity at Honfleur was above BAC (30 nmol. $\min ^{-1} \cdot \operatorname{mgprot}^{-1}$ ), meaning Honfleur mussels had not undergone any neurotoxic effects. The Mytilus sp. collected from the Wadden Sea had AChE activity equal to $\left(70 \pm 57 \mathrm{nmol} . \mathrm{min}^{-}\right.$ ${ }^{1} \cdot \operatorname{mgprot}^{-1}$ ), which classified them within BAC, as in Honfleur (Seine estuary) (Fig. 2 ; Tables 3 and 6). The Mytilus galloprovincialis mussels collected from Spain were immersed and maintained in cages at Cape Palos and Cartagena. AChE activity at Cape Palos $(85 \pm 77$ nmol.min $\left.{ }^{-1} \cdot \operatorname{mgprot}^{-1}\right)$ and Cartagena $\left(76 \pm 65\right.$ nmol.min $\left.{ }^{-1} \cdot \operatorname{mgprot}^{-1}\right)$ was less inhibited than in mussels from the Seine Bay, however this species was different (Mytilus galloprovincialis) and kept in cages. Nonetheless, a classification using comparisons of BAC (29 nmol.min ${ }^{-}$ $\left.{ }^{1} \cdot \mathrm{mgprot}^{-1}\right)$ and EAC (20 nmol.min $\left.{ }^{-1} \cdot \mathrm{mgprot}^{-1}\right)$ specific to $M$. galloprovincialis also classified the caged mussels within BAC. To resume, mussels were more inhibited in the Seine estuary but, despite high exposure in Honfleur, did not show AChE inhibition exceeding BAC. Precisions on the hybridization rate of Mytilus galloprovincialis and Mytilus edulis mussels would offer a more accurate comparison of the species sampled in the Atlantic and Mediterranean (Bierne et al., 2003). The influence of temperature on AChE inhibition is a foremost environmental factor. Temperatures on Spanish Mediterranean coasts $\left(17^{\circ} \mathrm{C}\right)$ were higher than in the Seine estuary $\left(16^{\circ} \mathrm{C}\right)$ and Wadden Sea $\left(14^{\circ} \mathrm{C}\right)$, situated further North. Nevertheless, despite temperature differences, exposure conditions on natural foreshores and in cages, together with very different typologies across the three stations, the results obtained at the three sites showed that AChE activity varied within a comparable metabolic response range. This major result has enabled EAC and BAC thresholds to be applied in the ICON programme. However, it does require an improved future integration of physiological parameters and environmental factors relative to each habitat for a more refined diagnostic at each site.

The measurements conducted in Seine Bay on mussels collected from natural beds at Honfleur and Le Moulard showed more fragile cellular integrity (LMS) versus mussels from 
Honfleur (Tables 3 and 6). Using Neutral red retention assay (NRR) analysis, haemocytes

570

571

572

573

574

575

576

577

578

579

580

581

582

583

584

585

586

587

588

589

590

591

592

593

594

595

596

597

598

599

600

601

602 permeability time was quantified at 43 minutes at Honfleur versus 75 minutes at Le Moulard. When the effect thresholds determined by OSPAR (Davies \& Vethaak, 2012) were applied, mussels from Honfleur were shown to be in a severely-stressed state ( $<50$ minutes), while mussels from Le Moulard were in a less-stressed exposure state. Metabolic compensation was nevertheless observed $(120<$ LMS Moulard < 50 minutes $)$ to maintain homeostasis. The Moulard station, chosen as a reference for comparison with the Seine estuary, had therefore undergone exposure pressure, although to a lesser degree than the Seine estuary station.

Comparative LMS measurements (Table 6) across the stations ( Martìnez-Gòmez et al., 2016) (Wadden Sea, Cartagena, Cape Palos and Honfleur) enabled BAC and EAC classification as follows: Wadden Sea and Honfleur> EAC and BAC (120 min) < Cape Palos, Cartagena and Le Moulard<EAC (50 min).

This classification of biological effects was coherent with chemical contamination revealing, for example, very high lead contamination at Cartagena and very high PCB contamination at Honfleur (Table 6). An harmonisation of the number of individuals analysed in each station must be done (SGIMC, 2011, UNEP/MAP 2011).

Imposex in dogwhelks Nucella lapilus was measured at three stations in Seine Bay in 2008 and 2009. Data was provided by the French observation network for chemical contaminants (ROCCH, 2014; http://wwz.ifremer.fr/envlit/resultats/surval__1), which is the national driving force behind the CEMP programme and descriptor 8 of the MSFD. The Villerville station to the South of the Seine mouth and Cape de la Hève to the North of the mouth (Fig. 2) are the most highly-exposed to the Seine panache. Both stations had very high VDSIs, with VDSI: 3 (Villerville) and 4 (Cape de la Hève) in 2008 and VDSI: 4 (Villerville) and 4 (Cape de la Hève) in 2009. These values classify the two Seine Bay stations in the upper EAC range: 2.0-4.0. The Pointe de la Loge station, located to the West of the Seine Bay and uninfluenced by the Seine panache, had VDSI: 0.5 in 2008 and VDSI: 0.71 in 2009, hence classifying it as BAC: 0.3 < VDSI Pointe de la Loge< EAC: 2.0-4.0. Imposex has been measured since 2003 by the ROCCH network. Between 2003 and 2009, average values were VDSI: 3.27 (Villerville), VDSI: 4.02 (Cape de la Hève) and VDSI: 1.03 (Pointe de la Loge) (ROCCH data). The syndrome of Dumpton wihich is a genetic aberration (Quintela et al., 2002) can be suspected at the most contaminated stations as Cape de la Hève and it would be studied in the future.

The integrated chemical-biological approach was applied according to the methods recommended by Davies et Vethaak, 2012. Chemical contamination, exposure and their 
603

604

605

606

607

608

609

610

611

612

613

614

615

616

617

618

619

620

621

622

623

624

625

626

627

628

629

630

631

632

633

634

635

636

subsequent effects are presented in 2008 and 2009 per site and, more precisely (Fig. 2), for each of the two sampling areas in Seine Bay (Seine estuary stations: Honfleur, Villerville and Cape de la Hève) and outside the Seine panache in the western part of the Seine Bay (Parfond, Le Moulard, Pointe de la Loge). The highest EAC contaminants (60\%) and EAC effects (50\%) were observed between 2008 and 2009 in the most-exposed area of the Seine estuary, versus the least-exposed area in the western Bay (Parfond, Le Moulard, Pointe de la Loge), with EAC contaminants (30\%) and EAC effects (15\%). The highest VDSI identified in the two stations of Cape de la Hève and Villerville are integrated into effects indicators and contribute to the portion (EAC 50\%) of red colour classification in the Seine estuary.

\section{Discussion}

Data synthesis was achieved by analyzing chemical contaminants, biomarkers and bioassays, for a full integration of the chemical and biological data developed by OSPAR /ICES within the CEMP monitoring programme (JAMP 2012). Numerous studies were achieved since about twenty years on the basis of an integrated approach of chemical contaminants and biomarkers. Major progress was realized on the robustness of the analytical methods of the bioassays and biomarkers and on the multi-biomarkers approach in the Baltic sea (Broeg and Lethonen, 2006), in Mediterranean sea (Tsangaris et al., 2011), in the North Sea (Brooks et al., 2011) and in the Atlantic ocean (Giltrap et al., 2013 ; Hylland et al., 2015). Theses studies applied a common list of biomarkers in different countries and some biomarker index. The more commonly biomarker index is the Integrated Biomarker Response (IBR) and related stress level concentrations of contaminants (PCBs, PAHs and metals measured in fish, mussels or sediment). Not any study have been assessed against internationally agreed criteria (Lyons et al., 2016) with fish, bivalves and gastropods before the ICON programme. This is among the most highly-advanced studies in Europe to date with regards to achieving an operational monitoring application of thresholds (BAC, EAC) within a monitoring programme (Hylland et al., 2016) and MSFD. Its reproduction on a local scale in France's Seine Bay has been enriched by the articles produced in this volume, incorporating the data produced at ICON sites as a whole.

34 The originality of this Seine Bay study with regards to the ICON programme lies in the fact that its sampling campaign covered four different species and seven different stations. The use of seven stations allowed the assembly of data obtained from two characteristic Seine Bay 
zones (Fig. 2). The first zone - "Seine estuary" - included the Villerville, Honfleur, Cape de

638 La Hève and Seine estuary stations. This zone is more heavily-contaminated as it is directly influenced by chemical inputs from the Seine panache, which flows northwards from the mouth (Fernandes et al., 1997 ; Gonzalez et al., 2001 ; Tecchio et al., 2015). The second zone, located to the West of Seine Bay, is little or unimpacted by the Seine panache. It includes the Moulard and Pointe de la Loge stations for bivalves study. Located further West and less impacted by the Seine panache, the Parfond station was chosen for flounder and dab collection. The results obtained (Fig. 2) allowed the quantification of high chemical contamination and biological effects using the EAC and BAC thresholds in the Seine estuary in four sentinel species (flounder, dab, mussel and dogwhelk). Interpretation of the results was consolidated by comparison with data obtained on a large geographical scale in the North Atlantic and Mediterranean (Kamman et al., 2016 ; Martìnez-Gòmez et al., 2016 ; Robinson et al., 2016 ; Hylland et al., 2016a ; Vethaak et al., 2016). This large-scale approach allowed the Seine estuary to be classified as one Europe's most highly-exposed sites in terms of chemical contaminants. This work also validates BAC and EAC thresholds by demonstrating coherencies on a local scale and at the ten or so European ICON sites studied separately. Of course, room for progress is necessary to fine-tune these thresholds per sentinel species and habitat in the future. These methodological developments will allow us to better-discern seasonal variations in chemical contamination and its effects on a local scale in order to better integrate the physiological cycle and most sensitive periods in the life cycle of the sentinel organisms. In-depth knowledge of the physiology of sentinel species is a key factor in interpreting the biological effects of chemical contaminants (Amiard and Rainbow, 2009). The integration of supporting physiological parameters in monitoring is therefore essential (Davies and Vethaak, 2012). Lastly, the acquisition of long-term series at a littlecontaminated site and a highly-contaminated site, as is the case in certain European countries (Hedman et al., 2001) offers the best prospects for consolidating monitoring results and suitable interpretations.

\section{Conclusion}


670 Seine estuary). Four sentinel species collected from seven stations were used to quantify 671 chemical contamination and biological effects in both zones, by applying the EAC and BAC 672 thresholds. The pertinence of the results obtained was consolidated by comparing the Seine 673 Bay data to data obtained from various stations included in the ICON programme, led on a 674 large geographical scale in the North-East Atlantic and Mediterranean. The EAC and BAC 675 chemical and biological thresholds were found to be applicable to a given species, whether on 676 a local level in the Seine estuary, or at a large geographical scale, hence allowing standardized 677 interpretation of the biomarkers, bioassays and chemical contamination studied in monitoring campaigns to assess good environmental status. This monitoring method, developed in the OSPAR/CEMP framework, is applicable to the MSFD. The use of an integrated chemicalbiological approach enabled comparison of exposure levels and effects on the selected model species; flounder, dab, mussels and gastropods. Progress must now be made to achieve a spatio-temporal interpretation by incorporating various physiological parameters, a new omic biomarkers and fine-tuning the EAC and BAC thresholds according to the specific habitats of sentinel species.

685

686

\section{Acknowledgements}

688

The authors wish to thank Professor J. Svavarson from the University of Iceland, Professor D.

690 Vethaak from the Deltares in Netherland and Dr. J. Baršiene from the Nature Research Centre in Vilnius, Lithuania for their contribution. This study was backed by the French National Office for Water and Aquatic Environments (ONEMA). Assistance was provided by the crew of Ifremer's "Gwendrez" boat. Imposex data and chemical data on mussels and sediment were

694 provided by the French National Network for the Observation of Chemical Contamination 695 (ROCCH).

\section{References}

699

700 Akcha, F., Vincent-Hubert, F., Leszkowicz, A., 2003. Potential value of the comet assay and DNA adduct measurement in dab (Limanda limanda) for the assessment of in situ exposure to 
702

703

704

705

706

707

708

709

710

711

712

713

714

715

716

717

718

719

720

721

722

723

724

725

726

727

728

genotoxic compounds. Edited in: Mutation research, Fundamental \& Molecular Mechanisms of Mutagenesis, Genetic Toxicology and Environmental Mutagenesis 534 : 21-32

Amiard-Triquet, C., Rainbow, P.S., 2009. Environmental Assessment of Estuarine Ecosystem: A Case Study. Edited by Amiard- Triquet Claude and Rainbow Philpp S. CRC Press as in imprint of Taylor Francis. ISBN: 998-1-4200-6260-1. 355pp

Baršiene, J., Lethonen, K.K., Koehler, A., Broeg, K., Vuorinen, P.J., Lang, T., Pemkowiak, J., Syvokiene, J., Dedonyte, V., Rybakovas, A., Repecka, A., Vuontisjärvi, H., Kopecka, J., 2006. Biomarker responses in flounder (Platichthys flesus) and mussel (Mytilus edulis) in the Klaipeda-Butinge area (Baltic Sea). Marine Pollution Bulletin 53 : 422-436

Beliaeff, B., Burgeot, T., 2002. Integrated biomarker response (IBR) a useful graphical tool for ecological risk assessment. Environmental Toxicology and Chemistry 1316-1322

Boeuf, B., Fritsch, O., 2016. Studying the implementation of the Water Framework Directive in europe: a meta-analysis of 89 journal articles. Ecology and Society 21(2) : 19. http://dx.doi.org/10.5751/ES-08411-210219

Bierne, N., Borsa, P., Daguin, C., Jollivet, D., Viard, F., Bonhomme, F., David, P., 2003. Introgression patterns in the mosaic hybrid zone between Mytilus edulis and Mytilus galloprovincialis. Mol. Ecol. 12 : 447-461

Bocquené, G., Galgani, F., 1998. Biological effects of contaminants : Cholinesterase inhibition by organophosphate and carbamate compounds. ICES Techniques in Marine Environmental Sciences 22. 12pp

Bodiguel X., Loizeau V., Le Guellec A.M., Roupasrd F., Philippon X., Mellon-Duval C., 2009. Influence of sex, maturity and reproduction on PCB and p,p'DDE concentrations and repartitions in the European hake (Merluccius merluccius, L.) from the Gulf of Lions (N/W. Meditterranean). Sci. Tot. Environ. 408 : 304-311.

Boon, J., Eijgenraam, F., Everasts, J., Dunker, J.C., 1989. A structure-activity relationship (SAR) approach towards metabolism of PCBs in marine animals from different trophic levels. Marine Environmental Research 27, 159-176 
Broeg, K., Lethonen, K.K., 2006. Indices for the assessment of environmental pollution of the Baltic Sea coasts : integrated assessment of a multi-biomarker approach. Mar. Pollut. Bull.53, $508-522$

Broeg, K., Gorbi, S., 2011. Methods to quantify lysosomal membrane stability and the accumulation of lipofuscin / D. Abele , J. Vázquez-Medina and T. Zenteno-Savín (editors), In: Oxidative Stress in Aquatic Ecosystems, Oxidative Stress in Marine Ecosystems, UK, Willey-Blackwell., 524 p., ISBN: 9781444335484 . doi: 10.1002/9781444345988.

Broeg, K., Kamman, U., Hoechert, N., Lang, T., 2015. Lysosomal membrane stability in the liver of dab (Limaznda limanda) - Applicability and reliability of assessment criteria under concrete contaminant-related Monitoring conditions coastal, estuarine, and offshore locations. Mar. Environ. Res. (in this issue). http://dx.doi.org/10.1016/j.manrenvres.2016.01.011

Brooks,S., Harman, C., Zaldibar, B., Izargirre, U., Glette, T., Marigómez I., 2011. Integrated biomarker assessment of the effects exerted by treated produced water from an onshore natural gas processing plant in the North Sea on the mussel Mytilus edulis. Mar. Pollut. Bull. $62,327-339$.

Burgeot T., G. Bocquené, G. Pingray, D. Godeffroy, J. Legrand, J. Dimeet, F. Marco, F. Vincent, Henocque, Y., Oger Jeanneret H., Galgani F., 1994. Monitoring biological effects of contamination in marine fish along french coasts by measurement of ethoxyresorufin-Odeethylase activity. Ecotoxicol. Environ. Saf. 131-147

Burgeot, T., Gagné, F., 2013. Ecotoxicology of estuaries in France and Québec, Canada. Environmental Science and Pollution Research 20, 601-770

Cachot J., Geffard O., Augagneur S., Lacroix S., Le Menach K., Peluhet L., Couteau J., Denier X., Devier M.H., Pottier D, Budzinski H., 2006. Evidence of genotoxicity related to high PAH content of sediments in the upper part of the Seine estuary (Normandy, France). Aquatic Toxicology 79 , 257-267.

Cachot, J., Cherel, Y., Larcher, T., Pfhol-Leskowicz, A., Laroche, J., Quiniou, L., Morin, J., Shmitz, J., Burgeot, T., Pottier, D., 2013. Histopathological lesions and DNA adducts in the liver of European flounder (Platichthys flesus) collected in the seine estuary versus two 
757 reference estuarine systems on the French Atlantic coast. Environmental Sciences and

758 Pollution Research 20, 723-737.

759 Carpentier, S., Moilleron, R., Beltran, C., Hervé, D., Thévenot, D., 2002. Quality dredged

760 material in the river Seine basin (France) II micropollutants. Sci.Total Environ. 299, 57-72

761 Chernik, M.R., 2007. Boostrap Methods: A guide for practitioners and researcher, 2nd

762 Edition. Wiley, New York. DOI: 10.1002/9780470192573

763 Chiffoleau, J.F., Auger, D., Chartier, E., Michel, P., Truquet, I., Ficht, A., Gonzalez, J.L.,

764 Romana, L.A., 2001. Spatiotemporal changes in cadmium contamination in the Seine estuary

765 (France). Estuaries 24, 1029-1040

766 Dauvin, J.C., 2007. Paradox of estuarine quality: benthic indicators and indices, consensus or 767 debate for the future. Mar. Pollut. Bull. 55, 271-281

768 Davies I.M., Vethaak, A.D., 2012. Integrated marine environmental monitoring and their 769 effects. ICES cooperative Research Report No. 315. 277 pp

770 Davies, I.M., Gubbins, M., Hylland, K., Maes, T., Martìnez-Gòmez, C., Moffat, C., Burgeot, 771 T., Thain, J., Vethaak, A.D., 2012. Guidelines for the integrated monitoring and assessment of 772 contaminants and their effects. In I.M. Davies \& A.D. Vethaak (Eds.), Integrated marine 773 environmental monitoring and their effects (pp. 5-16). Copenhagen, Denmark : ICES.

774 Davison, A., Hinkley, D.V., 1997. Boostrap Methods and Their Application. Cambridge 775 University Press. 28 p.

776 Devin S., T. Burgeot, L. Giambérini, Minguez L., Pain-Devin, S., 2013. The integrated 777 biomarker response revisited : optimization to avoid misuse. Environmental Sciences and 778 Pollution Research 216,7685.

779 EC 2008. Directive 2008/56/EC of the European Parliament and of the council of 17 june 7802008 establishing a framework community action in the field of marine environmental policy 781 (Marine Strategy Framework Directive). Official J. Eur. Union I.1 64.19 
782 Feist, S.W., Lang, G.D., Stentiford, A., Kölher, A., 2004. Biological effects of contaminants:

783 use of liver pathology of the European dab (Limanda limanda) and flounder (Platichthys

784 flesus) for monitoring. ICES Techniques in Marine Environmental Sciences 38, 42pp

785 French legislative decree 2012. Arrêté du 17 décembre 2012 relatif à la définition du bon état 786 écologique des eaux marines. NOR: DEVL1240628A. Ministère de l'Ecologie et du 787 Développement Durable et de l'Energie. 30 Décembre 2012. Journal Officiel de la 788 République Française 27pp

789

790

791

792

793

794

795

796

797

798

799

800

801

802

803

804

805

806

807

808

809

Fernandes, M.B., Sicre, M.A., Boireau, A., Tronczynski, J., 1997. Hydrocarbon distribution in the Seine Estuary: Biogenic Polyaromatic and Aliphatic hydrocarbons. Estuaries 20: 281-290.

Giltrap, M., Ronan, J., Hardenberg, S.? Parkes, G., McHugh, B., McGovern, E., Wilson, J.G., 2013. Assessment of biomarkers in Mytilus edulis to determine good environmental status for implementation of MSFD in Ireland. Mar. Pollut. Bull. 71 (1-2), 240-249.

Gonzalez, J.L., Thouvenin, B., Dange, C., Chiffoleau, J.F., Fiandrino, A., 2001. Modeling of cadmium speciation and dynamics in the Seine estuary (France). Estuaries, 24 (6B) 10411055.

Gubbins, M., Stanad, J., Thain, J., Davies, I.M., 2012. Assessment criteria for imposex in marine gastropods affected by exposure to organotin compounds. In Davies I.M., Vethaak, A.D., (Eds), Integrated marine environmental monitoring and their effects. ICES cooperative Research Report No. 315. 277

Hedman, J.E., Rüdel, H., Gerken, J., Bergek, S., Strand, J., Quack, M., Appelberg, M., Förlin, L., Tuvikene, A., Bignert, A., 2011. Eelpout (Zoarces viviparus) in marine environmental monitoring. Marine Pollution Bulletin 62 , 2015-2029.

Hylland, K., Gubbins, M., Robinson, C., Lang, T., Vethaak, A.D., Martìnez-Gòmez, C., Burgeot, T., Svavarsson, J., Thain, J.E., 2012. Theory and practice of integrated monitoring in marine ecosystems-The ICON programme. Comparative Biochemistry and Physiology Part A. Molecular and Integrative Physiology 163, S51-S52. 10.1016/j.cbpa.2012.05.149

Hylland, K., Burgeot, T., Martìnez-Gòmez, C, Lang T., Robinson, C.D, Svavarsson, J., Thain, J.E., Robinson, C.D, Gubbins, M.J., 2015. How can we quantify impacts of contaminants un 
810 marine ecosystems? The ICON project. Mar. Environ. Res. (in this issue).

811 http://dx.doi.org/10.1016/j.manrenvres.2015.11.006

812 Hylland, K., Robinson, C.D., Burgeot, T., Martìnez-Gòmez, C., Lang T., Svavarsson, J., 813 Thain, J.E., Vethaak, A.D., 2016a. Integrated chemical and biological assessment of 814 contaminant impacts in selected European coastal and offshore marine areas. Mar. Environ.

815 Res. (in this issue). http://dx.doi.org/10.1016/j.manrenvres.2016.05.014

816 Hylland, K.,Skei, B.B., Brunborg, G., Lang, T., Gubbins, M.J., Le Goff, J., Burgeot, T.,

817 2016b. DNA damage in dab (Limanda limanda) and haddock (Melanogrammus aeglefinus)

818 from European seas. Mar. Environ. Res. (in this issue).

819 http://dx.doi.org/10.1016/j.manrenvres.2016.01.001

820 Idardare, Z., Chiffoleau, J.F., Moukrim, A., Alla, A., Auger, D., Lefrere, L., Rozuel, E., 2008.

821 Metal concentrations in sediment and Nereis diversicolor in two Moroccan lagoons: Khnifiss

822 and Oualidia. Chemistry and Ecology 24(5), 329-340

823 JAMP 2012. Joint Assessment Monitoring Programme (JAMP) Guidelines for the Integrated 824 Monitoring and Assessment of Contaminants and their effects. Ospar Commission. 22p

825 Jaouen-Madoulet, A., Abarnou, A., Le Guellec, A.M., Loizeau, V., Leboulenger, F., 2000.

826 Validation of an analytical procedure for polychlorinated biphenyls, coplanar polychlorinated 827 biphenyls and polycyclic aromatic hydrocarbons in environmental samples. J .Chromatogr. A. $828 \quad 886,153-73$

829 Kamman, U., Akcha, F., Budzinski, H., Burgeot, T., Gubbins, M.J., Lang, T., Le Menach, K., 830 Vethaak, D., Hylland, K., 2016. PAH metabolites in fish bile: from the Seine estuary to 831 Iceland. Mar. Environ. Res. (in this issue).

832 http://dx.doi.org/10.1016/j.manrenvres.2016.02.014

833 Lafite, R., Billen, G., Dauvin, J.C., Chiffoleau, J.F., 2001. The Seine Estuary: a man-altered 834 macrotidal system. Estuaries 24 (special issue).

835 Lang, T., Wosniok, W., 2008. The Fish Desease Index : a method to assess wild fish disease 836 data in the context of marine environmental monitoring . ICES CM 2008/D:01, 13 pp. 
837

838

839

840

841

842

843

844

845

846

847

848

849

850

851

852

853

854

855

856

857

858

859

860

861 as common indicators for marine biomonitoring programmes in Europe : The ICON

862 experience. Mar. Environ. Res. (in this issue).

863 http://dx.doi.org/10.1016/j.manrenvres.2015.10.012

Lang, T., Feist, S.W., Stentiford, G.D., Bignell, J.P., Vethaak, A.D., Wosniok, W., 2016. Diseases of dab (Limanda limanda) : Analysis and assessment of data on externally visible diseases, macroscopic liver neoplasms and liver histopathology in the North Sea, Baltic Sea and off Iceland. Mar. Environ. Res. (in this issue). http://dx.doi.org/10.1016/j.manrenvres.2015.12.009

Le Hir, P., Ficht, A., Silva Jacinto, R., Lesueur, P., Dupont, J.P., Lafite, R., Brenon, I., Thouvenin, B., Cugier, P., 2001. Fine Sediment Transport and Accumulations at the Mouth of the Seine Estuary (France). Estuaries $24,950-963$

Lyons, B., Davies, I.M., 2012 . Background DNA adducts of polycyclic aromatic hydrocarbons. 60-67. In Davies I.M., Vethaak, A.D., (Eds), Integrated marine environmental monitoring and their effects. ICES cooperative Research Report No. 315. 277

Lyons, B., Bignell, J.P., Stentiford, G.D., Bolam, T.P.C., Rummey, H.S., Bersuder, P., Barber, J.L., Askem, C.E, Nicolaus, M.E.E., Maes, T., 2016. Determining Good Environmental Status under the Marine Strategy Framework Directive: Case study for descriptor 8 (chemical contaminants). Mar. Environ. Res. (in this issue). http://dx.doi.org/10.1016/j.manrenvres.2015.12.010

Martìnez-Gómez, C., Benedicto, J., Campillo, J.A., Moore, M., 2008. Application and evaluation of the neutral red retention (NRR) assay for lysosomal stability in mussel populations along the Iberian Mediterranean coast . J. Environ. Monit. 10 , 490-499

Martìnez-Gómez, C., and Thain, J., 2012. Background document: stress on stress (SOS) in bivalve molluscs. In Davies I.M., Vethaak, A.D., (Eds), Integrated marine environmental monitoring and their effects. ICES Cooperative Research Report No. 315. 277

Martìnez-Gómez, C., Robinson, C.D., Burgeot, T., Gubbins M., Halldórson, H.P., Albentosa, M., Bignell, J.P., Hylland, K., Robinson, C.D., 2015. Biomarkers of general stress in mussels 
864 Mazéas, O., Budzinski, H., 2005. Solid-phase extraction and purification for the 865 quantification of polycyclic aromatic hydrocarbon metabolites in fish bile. J. Anal. Bioanal. 866 Chem $383,985-90$

867 Minier, C., Levy, F., Rabel, D., Bocquené, G., Godefroy, D., Burgeot, T., Leboulenger, F., 868 2000. Flounder health status in the Seine Bay. A multibiomarker study. Mar. Environ. Res. $86950,373-377$.

870 Millwards G.E., Jha, A.N., Minier, C., Pope N.D., 2015. The English Channel and its 871 catchments : Status and responses to contaminants. Editorial. Marine Pollution Bulletin 95, 872 523-528.

873

874

875

876 877

Moore M.N., Lowe D., Kölher A., 2004. Biological effects of contaminants measurement of lysosomal stability. ICES Tech. Mar. Environ. Sci. 36-39.

Munschy, C., Moisan, K., Tronczynski, J., 2003. PCDDS and PCDFs in the marine flatfish Dab ( Limanda limanda) from a contaminated estuary in France. Organohalogen Compounds $62,157-160$.

Murk, A.J., Legler, J., Denison, M.S., Giesy, J.P., Guchte, C., van de., Brouwer, A., 1996 . Chemical-activated luciferase gene expression (CALUX): A novel in vitro bioassay for Ah receptor active compounds in sediments and pore water. Fundamental and Applied Toxicology 33, 149-160

Nahklé, K., Cossa, D., Claisse, D., Beliaeff, B., Simon, S., 2007. Cadmium and mercury in Seine Estuary flounders and mussels: the results of two decades of monitoring. ICES Journal of Marine Science 64, 929-938 pp

Ospar Commission 2009. Background document on CEMP Assessment Criteria for QSR 2010. www.osparg.org. ISBN 978-1-907390-08-1. Monitoring and Assessment series. 23p

Quintila, M., Barreiro, J., Ruiz, J.M., 2002. Dumpton syndrome reduces the tributyltin (TBE) sterilising effect Nucella lapillus (L.) by limiting the development of the imposed vas deferens. Mar. Environ. Res. 657-660.

Robinson, C.D., Webster, L., Martìnez-Gòmez, C., Burgeot, T., Gubbins, M.J., Thain, J.E., 891 Vethaak, A.D., McIntosh, A.D., Hylland, K., 2016. Assessment of contaminant 
892

893

894

895

896

897

898

899

900

901

902

903

904

905

906

907

908

909

910

911

912

913

914

915

916

917

918

concentrations in sediments, fish and mussels sampled from the North Atlantic and European regional seas within ICON project. Mar. Environ. Res. (in this issue). http://dx.doi.org/10.1016/j.manrenvres.2016.04.005

Rocher, B., Le Goff, J., Peluhet, L., Briand, M., Manduzio, H., Gallois, J., Devier, M.H., Geffard, O., Gricourt, L., Augagneur, S., Budzinski, H., Pottier, D., André, V., Lebailly, P., Cachot, J., 2006. Genotoxicant accumulation and cellular defence activation in bivalves chronically exposed to waterborne contaminants from the Seine river. Aquatic Toxicology 79 , $65-77$.

Roddie, B., Thain, J., 2001. Biological effects of contaminants : Corophium sp. Sediment bioassay and toxicity test. ICES Techniques in Marine Environmental Sciences 29. 22pp.

Scott, A.P., Hylland, K., 2002. Biological effects of contaminants : radioimmunoassay (RIA) and enzyme-linked immunosorbent assay (ELISA) techniques for the measurement of marine fish vitellogenins. ICES Techniques in Marine Environmental Sciences 31. 22pp

Stagg, R., McIntosh, A., 1998. Biological effects of contaminants. Determination of CYP1Adependent mono-oxygenase activity in dab by fluorimetric measurement of EROD activity. ICES Techniques in Marine Environmental Sciences 23. 16 pp.

SGIMC 2011. Report of the Study Group on Integrated Monitoring of Contaminants and Biological Effects (SGIMC). 14-18 march 2011, Copenhagen, Denmark. ICES CM 2011/ACOM : 30. 265 pp.

Stentiford, G.D., 2012. Background document : intersex (ovotestis) measurement in marine and estuarine fish. 94-100 pp. In Davies I.M., Vethaak, A.D., (Eds), Integrated marine environmental monitoring and their effects. ICES cooperative Research Report No. 315. 277 $\mathrm{pp}$

Tecchio, S., Tous Ruis, A., Dauvin, J.C., Lobry, J., Lasalle, G., Morin, J., Bacq, N., Cachera, M., Chaalali, A., Ching Villanueva, M., Niquil, N., 2015. The mosaic of habitats of the Seine estuary : Insights from food-web modelling and network analysis. Ecological Modelling 312 : 91-101 
919 Thain, J.E., 1991. Biological effects of contaminants: oyster (Crassostrea gigas) embryo

920 bioassay. ICES Techniques in Marine Environmental Sciences 29, 16pp.

921 Thain, J.E., Hurst, M.R., Thomas, K.V., 2006. Determination of dioxin-like activity in 922 sediments from the East Shetland basin. Organohal Compounds 68, 185-188.

923 Tsangaris, C., Hatzianestis, I., Catsiki, V.A., Kormas, K.A., Strogyloudi, E., Neofitou, C., 924 Andral, B., Galgani, F., 2011. Active biomonitoring in Greek coastal waters: Application of 925 the integrated biomarker response index in relation to contaminant levels in caged mussels. 926 Science of the Total Environment 359-365.

927 UNEP/MAP, 2011. United Nations Environment Programme/Mediterranean Action Plan. 928 Development of assessment criteria for hazardous substances in the Mediterranean. 929 Consultation meeting to review MED POL monitoring activities. Athens, November 2011. 930 UNEP (DEPI)MED WG. 365/inf.8. 1 November 2011.

931 USEPA 1998. Evaluation of dredge material proposed for discharge in waters of the US. 932 Testing manual. United states Environmental Protection Agency. EPA/823F/98/005.

933 Vethaak, A.D., Davies, I.M., Thain, J., Gubbins, M.J., Martìnez-Gòmez, C., Robinson, C., 934 Moffat, C.F., Burgeot, T., Maes, T., Wosniok, W., Giltrap, M., Lang, T., Hylland, K. 2015. 935 Integrated indicator framework and methodology for monitoring and assessement of 936 hazardous substances and their effects in the marine environment. Mar. Environ. Res. (in this 937 issue). http://dx.doi.org/10.1016/j.manrenvres.2015.09.010

938 Vethaak, A.D., Hamers, T., Martìnez-Gòmez, C., Kamstra, J.H., de Weert, J., Leonards, 939 P.E.G., Smedes, F., 2016. Toxicity profiling of marine surface sediments : A case study using 940 rapid screening bioassays of exhaustive total extracts, elutriates and passive sampler extracts. 941 Mar. Environ. Res. (in this issue). http://dx.doi.org/10.1016/j.manrenvres.2016.03.002

942 Viarengo, A., Lowe, D., Bolognesi C., Fabbri, E., Koelher, A., 2007. The use of biomarkers 943 in biomonitoring: a 2-tier approach assessing the level of pollutant-induced stress syndrome in 944 sentinel organisms. Comp. Biochem. Physiol.Part C Toxicol. Pharmacol. 146 (3), 281-300. 
Tables and figures

947

Table 1: Sampling site information and samples analysed in the two local areas (The Seine Bay and the Seine estuary ) and in the other ICON sites .

950

Table 2: Bioassays in sediment. Larval abnormalities in oyster, Corphium arenarium and DR-

952 CALUX bioassay for screening of dioxin-like compounds and physicochemical 953 characteristics of ICON sediment.

954 ND: No response detected, QL: Limit of Quantification, DL: Detection limit.

955 QL DR-Calux pg TEQ/g sediment dry weight : 0.5 and Quantification DL DR-CALUX pg $956 \mathrm{TEQ} / \mathrm{g}$ sediment dry wt (dry weight) : 1.5

$957 *$ Blank of extraction for DR-CALUX <DL. ** Blank of extraction for the cytotoxicity at the 958 highest concentration: No. Assessment criteria BAC and EAC published in the cooperative 959 report Davies and Vethaak, 2012.

960 Number of replicats: Three replicats for larval abnormalities in oyster, Corphium arenarium 961 and DR-CALUX bioassay.

962

963 Table 3: Biomarkers (mean \pm Standard deviation) analysis in Limanda limanda, Platichthys 964 flesus, Mytilus sp. and Nucella lapillus and OSPAR CEMP derived assessment criteria (BAC; 965 Background Assessment Criteria; EAC: Environmental Assessment Criteria).

$966 *$ Comet in dab; **1OHpyrène in cod; *** EROD activity in male; ${ }^{\S}$ in dab Portuguese 967 Atlantic water. $\%$ prevalence in dab; ND: no determined

$968 \mathrm{n}=10$, number of individual analyzed for each biomarker

969 Table 4: Contaminants concentrations in sediment (mg. $\mathrm{kg}^{-1}$ d.w. for metals, $\mu \mathrm{g} . \mathrm{kg}^{-1}$ d.w. for 970 organic), in dab, flounder, mussels (mg.kg ${ }^{-1}$ d.w. for metals, $\mu \mathrm{g} . \mathrm{kg}^{-1}$ d.w. for organic) and 971 OSPAR CEMP derived assessment criteria for PAHs, CBs and trace metals in sediment, dab, 972 flounder, mussels (BAC; Background Assessment Criteria; EAC: Environmental Assessment 973 Criteria; ERL: Effect Range Low; EQS: Environmental Quality Standard; MPC: Maximum 974 Permitted Concentration) in Robinson et al., 2016. BACs in sediment are normalised to $2.5 \%$ 975 organic carbon for PAHs and $\mathrm{BCs}$, and to 5\% aluminium for trace metals. (Ospar 976 commission 2009. Background document on CEMP Assessment Criteria for QSR 2010. . 977 www.osparg.org. ISBN 978-1-907390-08-1. Monitoring nd Assessment series. 23p.) 
$978 *$ Data obtained from national monitoring programmes, not from the ICON project. TR:

979 Below limit of quantification.

$980 \%$ Lipid in 2009 in dab (Seine estuary : 3.47\% and Parfond: 5.70\%) and in flounder (2 Seine 981 estuary: $3.65 \%$ and Parfond : $3.05 \%$ )

$982{ }^{1}$ CBs d.w. in dab and flounder liver in 2008 ( $n=1$ pool of 15 individuals per site)

$983{ }^{2}$ CBs d.w. in dab and flounder muscle in 2009 ( $n=1$ pool of 15 individuals per site)

$984{ }^{3}$ in fish muscle

$985{ }^{4} \mathrm{Cd}$ and $\mathrm{Pb}$ d.w. in liver

986

Table 5: PAH metabolites analysed in dab and flounder in the Seine estuary. PAH metabolites 1-hydroxypyrene (1OHPyr), 1-hydroxyphenenthrene (1OHPhen), 1hydroxychrysene (1OHchrys) and sum of 3-hydroxybenzo(a)pyrene and 9 hydroxybenzo(a)pyrene ( $\mathrm{OHHBA}$ ) given as mean, minimum and maximum per sex of dab and flounder in $\mathrm{ng} \cdot \mathrm{g}^{-1}$ of bile ( $\mathrm{n}:$ number of individuals).

992

Table 6: Acetycholinesterase (AChE) activities and Lysosomal stability (LMS) in mussels.

994 AChE activity was analysed in the same laboratory (Ifremer, France). LMS was analysed in 995 three different laboratories (IOE in Spain: Cartagena and Cape Palos, Deltares in Netherland: 996 Wadden sea and University of le Havre in France: Honfleur and Le Moulard). (n : number of 997 individuals)

1000 Figure 1. Sampling location of the Seine bay in France and location of the stations selected in 1001 the ICON programme.

1003 Figure 2. Seine Bay location with two areas studied in the Seine estuary (Seine estuary, Cap 1004 de la Hève, Villerville, Honfleur) and the West of the Seine Bay (Parfond, Pointe de la loge, 1005 Le Moulard). 
ACCEPTED MANUSCRIPT

\begin{tabular}{|c|c|c|c|c|c|c|c|c|c|c|c|c|c|c|c|c|c|c|}
\hline \multirow[t]{3}{*}{ Dates } & \multirow[t]{3}{*}{ Biomakers } & \multicolumn{2}{|c|}{$\begin{array}{l}\text { Limanda } \\
\text { limanda }\end{array}$} & \multicolumn{2}{|c|}{$\begin{array}{c}\text { Platichthys } \\
\text { flesus }\end{array}$} & \multicolumn{2}{|c|}{ Mytilus sp. } & \multicolumn{3}{|c|}{$\begin{array}{c}\text { Nucella } \\
\text { lapilus }\end{array}$} & \multirow{3}{*}{$\begin{array}{l}\text { BAC } \\
\text { Limanda } \\
\text { limanda }\end{array}$} & \multirow{3}{*}{$\begin{array}{l}\mathbf{E A C} \\
\text { Limanda } \\
\text { limanda }\end{array}$} & \multirow{3}{*}{$\begin{array}{l}\text { BAC } \\
\text { Platichthy } \\
\text { sflesus }\end{array}$} & \multirow{3}{*}{$\begin{array}{l}\text { EAC } \\
\text { Platichthys } \\
\text { flesus }\end{array}$} & \multirow{3}{*}{$\begin{array}{l}\text { BAC } \\
\text { Mytilus } \\
\text { sp. }\end{array}$} & \multirow{3}{*}{$\begin{array}{l}\text { EAC } \\
\text { Mytilu } \\
\text { s sp. }\end{array}$} & \multirow{3}{*}{$\begin{array}{l}\text { BAC } \\
\text { Nucella } \\
\text { lapilus }\end{array}$} & \multirow{3}{*}{$\begin{array}{l}\text { EAC } \\
\text { Nucella } \\
\text { lapilus }\end{array}$} \\
\hline & & $\begin{array}{l}\text { Seine } \\
\text { estuary }\end{array}$ & Parfond & Seine estuary & Parfond & Honfleur & Le Moulard & $\begin{array}{l}\text { Pointe de la } \\
\text { loge }\end{array}$ & Villerville & $\begin{array}{l}\text { Cap de la } \\
\text { Heve }\end{array}$ & & & & & & & & \\
\hline & & $\begin{array}{l}49^{\circ} 26.067 \mathrm{~N} \\
00^{\circ} 00.566 \mathrm{E}\end{array}$ & $\begin{array}{c}49^{\circ} 19.021 \mathrm{~N} \\
000^{\circ} 09.072 \\
\mathrm{~W}\end{array}$ & $\begin{array}{l}{ }^{49^{\circ}} 26.067 \mathrm{~N} \\
00^{\circ} 00.566 \mathrm{E}\end{array}$ & $\begin{array}{l}49^{\circ} 19.021 \mathrm{~N} \\
000^{\circ} 0.9072 \\
\mathrm{~W}\end{array}$ & $\begin{array}{l}49^{\circ} 25.08 \mathrm{~N} \\
00^{\circ} 13.59 \mathrm{E}\end{array}$ & $\begin{array}{r}49^{\circ} 65.907 \mathrm{~N} \\
1^{\circ} 23.30348 \mathrm{~W}\end{array}$ & $\begin{array}{l}49^{\circ} 42.403 \mathrm{~N} \\
1^{\circ} 25.164 \mathrm{~W}\end{array}$ & $\begin{array}{l}49^{\circ} 24.220 \mathrm{~N} \\
0^{\circ} 07.432 \mathrm{E}\end{array}$ & $\begin{array}{l}49^{\circ} 30.573 \mathrm{~N} \\
0^{\circ} 04.0987 \mathrm{E}\end{array}$ & & & & & & & & \\
\hline 17.09 .2008 & $\begin{array}{l}\text { EROD } \\
\mathrm{pmol} / \mathrm{min} / \mathrm{mgprot}\end{array}$ & $26.5 \pm 18$ & $19.2 \pm 12$ & $28.1 \pm 11$ & $16.3 \pm 10$ & & & & & & $147 * * *$ & ND & $24 * * *$ & $\mathrm{ND}$ & & & & \\
\hline $\begin{array}{l}17.09 .2008 \\
17.09 .2008\end{array}$ & $\begin{array}{l}\text { ACE nmol/min/mgprot } \\
\text { DNA adduct nm }\end{array}$ & $\begin{array}{c}231 \pm 162 \\
0.3 \pm 0.3\end{array}$ & $\begin{array}{l}276 \pm 195 \\
2.7 \pm 3.3\end{array}$ & $\begin{array}{l}185 \pm 122 \\
1.3 \pm 1.1\end{array}$ & $\begin{array}{c}256 \pm 114 \\
0.7 \pm 0.6\end{array}$ & $43 \pm 3$ & $76 \pm 5$ & & & & $\begin{array}{c}150^{\S} \\
1\end{array}$ & $\begin{array}{r}105^{8} \\
6\end{array}$ & $\begin{array}{c}235 \\
1\end{array}$ & $\begin{array}{r}165 \\
6\end{array}$ & 30 & 21 & & \\
\hline 17.09.2008 & $\begin{array}{l}\text { adduct/molibNA } \\
\text { PAH metabolite (1OH } \\
\text { PYR ng/g) }\end{array}$ & $534 \pm 305$ & $290 \pm 175$ & $348 \pm 183$ & $225 \pm 112$ & & & & & & $483^{* *}$ & $528^{* * *}$ & $483^{* *}$ & $528^{* * *}$ & & & & \\
\hline $\begin{array}{l}17.09 .2008 \\
17.092008\end{array}$ & $\begin{array}{l}\mathrm{MN} / 1000 \text { cells } \\
\text { Vto } \mu \mathrm{g} / \mathrm{ml}\end{array}$ & $0.51 \pm 0.47$ & $\mathrm{ND}$ & $\begin{array}{l}0.460 .41 \\
79+32\end{array}$ & $\mathrm{ND}$ & & & & & & 0.5 & ND & 0.3 & $\mathrm{ND}$ & & & & \\
\hline $\begin{array}{l}17.09 .2008 \\
\end{array}$ & Comet $\%$ DNA Tail & ND & $\mathrm{ND}$ & $10 \pm 6.3$ & $8.2 \pm 6.9$ & & & & & & 5 & $\mathrm{ND}$ & $5^{*}$ & $\mathrm{ND}$ & & & & \\
\hline 17.09 .2008 & Intersex (\% prevalence & $\mathrm{ND}$ & 1 & 8 & 2 & & & & & & & & 5 & & & & & \\
\hline 17.09.2008 & $\begin{array}{l}\text { External pathologies } \\
\text { Hyperpigmentation (\% } \\
\text { Prevalence) }\end{array}$ & 3.9 & 0.3 & 2.4 & 0.2 & & & & & & & & & & & & & \\
\hline 17.09.2008 & $\begin{array}{l}\text { External pathologies: } \\
\text { skin ulceration } \\
\text { (\% Prevalence) }\end{array}$ & 3.1 & 0.2 & 1.8 & 0.3 & & & & & & & & & & & & & \\
\hline 19.09.2008 & $\begin{array}{l}\text { Lysosomal stability } \\
\text { (Min) }\end{array}$ & 6 & & & & 40 & 60 & & & & 20 & 10 & & & $>120$ & $<50$ & & \\
\hline $\begin{array}{l}19.09 .2008 \\
23.09 .2009\end{array}$ & $\begin{array}{l}\text { Stres on stress LT50 } \\
\text { ERD } \\
\text { pmol/min/mgprot }\end{array}$ & $24.6 \pm 14.1$ & $17.5 \pm 17.3$ & $4.2 \pm 2.5$ & $11.0 \pm 9.5$ & 9 & 15 & & & & $147 * * *$ & ND & $24 * * *$ & $\mathrm{ND}$ & 10 & 5 & & \\
\hline $\begin{array}{l}23.09 .2009 \\
23.09 .2009\end{array}$ & 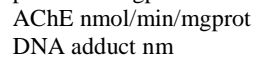 & $\begin{array}{l}182+105 \\
2.6 \pm 1.9\end{array}$ & $\begin{array}{l}208 \pm 118 \\
1.5 \pm 1.4\end{array}$ & $\begin{array}{l}225 \pm 174 \\
2.2 \pm 1.6\end{array}$ & $\begin{array}{l}430 \pm 321 \\
2.6 \pm 2.1\end{array}$ & & & 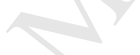 & & & $\begin{array}{c}150 \\
1\end{array}$ & $\begin{array}{r}105 \\
6\end{array}$ & 235 & $\begin{array}{r}165 \\
6\end{array}$ & & & & \\
\hline 23.09.2009 & $\begin{array}{l}\text { adduct/molDNA } \\
\text { PAH metabolite }(1 \mathrm{OH}\end{array}$ & $123 \pm 99$ & $29 \pm 12$ & $107 \pm 53$ & $37 \pm 25$ & & & & & & $483^{* *}$ & $528 * *$ & $483^{* * *}$ & $528^{* * *}$ & & & & \\
\hline 23.09.2009 & $\mathrm{MN} / 1000$ cells & $0.68 \pm 0.55$ & $0.54 \pm 0.45$ & $0.58 \pm 0.54$ & $\mathrm{ND}$ & & & & & & 0.5 & $\mathrm{ND}$ & 0.3 & $\mathrm{ND}$ & & & & \\
\hline $\begin{array}{l}23.09 .2009 \\
23.02009\end{array}$ & $\mathrm{Vtg} \mu \mathrm{g} / \mathrm{ml}$ & ND & ND & $\mathrm{ND}$ & $\begin{array}{l}8.5 \pm 6.2 \\
0.03\end{array}$ & & & & & & & & 0.13 & ND & & & & \\
\hline $\begin{array}{l}23.09 .20099 \\
23.09 .2009\end{array}$ & $\begin{array}{l}\text { Comet } \% \text { DNA Tail } \\
\text { Intersex (\% prevalence) }\end{array}$ & $\begin{array}{c}\mathrm{ND} \\
0\end{array}$ & $\begin{array}{c}\mathrm{ND} \\
0\end{array}$ & $\begin{array}{l}15.5 \pm \pm 0.5 \\
5.5\end{array}$ & $\begin{array}{l}12.7 \pm 9.3 \\
1\end{array}$ & & & & & & 5 & & $\begin{array}{l}5 * \\
5 *\end{array}$ & $\begin{array}{l}\mathrm{ND} \\
\mathrm{ND}\end{array}$ & & & & \\
\hline 23.09.2009 & $\begin{array}{l}\text { External pathologies } \\
\text { Hyperpigmentation (\% }\end{array}$ & 2.7 & 0.6 & 1.1 & 0.4 & & & & & & & & & & & & & \\
\hline 23.09.2009 & $\begin{array}{l}\text { Prevalence) } \\
\text { External pathologies: } \\
\text { skin ulceration } \\
\text { (\% Prevalence) }\end{array}$ & 0.9 & 0.3 & 0.6 & 0.1 & & & & & & & & & & & & & \\
\hline $\begin{array}{l}03.2008 \\
032009\end{array}$ & $\begin{array}{l}\text { VDSI } \\
\text { VDSI }\end{array}$ & & & & & ) & & $\begin{array}{l}0.5 \\
0.71\end{array}$ & 3 & $\begin{array}{l}4 \\
4\end{array}$ & & & & & & & $<0.3$ & $2.0-4.0$ \\
\hline
\end{tabular}

Table 3 


\begin{tabular}{|c|c|c|c|c|c|c|c|c|c|c|c|c|c|c|c|c|c|c|}
\hline \multirow[t]{2}{*}{ Station } & \multirow[t]{2}{*}{ Date } & \multirow[t]{2}{*}{ Position } & \multirow[t]{2}{*}{ Species } & \multirow[t]{2}{*}{$\mathbf{n}$} & \multirow[t]{2}{*}{ Sex } & \multirow[t]{2}{*}{ Lenght (cm) } & \multicolumn{3}{|c|}{ 10HPyr } & \multicolumn{3}{|c|}{ 1-OH-Phen } & \multicolumn{3}{|c|}{ 1OH-Chrys } & \multicolumn{3}{|c|}{ 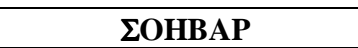 } \\
\hline & & & & & & & mean & $\min$ & $\max$ & mean & $\min$ & $\max$ & mean & $\min$ & $\max$ & mean & $\min$ & $\max$ \\
\hline Seine estuary & 19.09 .2008 & $\begin{array}{l}49^{\circ} 26.067 \mathrm{~N} \\
00^{\circ} 00.566 \mathrm{~W}\end{array}$ & Dab & 10 & Male & $24.0 \pm 1.41$ & 401.9 & 165 & 813 & 19.77 & 3 & 59 & 31.75 & 9 & 41 & 731.34 & 423.72 & 1339.51 \\
\hline Seine estuary & 19.09.2008 & $\begin{array}{l}49^{\circ} 26.067 \mathrm{~N} \\
00^{\circ} 00.566 \mathrm{~W}\end{array}$ & Dab & 10 & Female & $20.3 \pm 0.41$ & 467.5 & 43 & 899 & 23.28 & & 60 & 14.2 & 7 & 33 & 548.37 & 59.26 & 995.16 \\
\hline Seine estuary & 19.09.2008 & $\begin{array}{l}49^{\circ} 26.067 \mathrm{~N} \\
00^{\circ} 00.566 \mathrm{~W}\end{array}$ & Flounder & 10 & Male & $29.9 \pm 1.64$ & 297.77 & 160 & 694 & & 2 & 21 & 26.66 & 16 & 37 & 553.33 & 361 & 1470 \\
\hline Seine estuary & 19.09.2008 & $\begin{array}{l}49^{\circ} 26.067 \mathrm{~N} \\
00^{\circ} 00.566 \mathrm{~W}\end{array}$ & Flounder & 10 & female & $29.2 \pm 2.16$ & 388.77 & 173 & 763 & 6.7 & 1 & 11 & 11.57 & 3 & 25 & 632.32 & 209 & 1046 \\
\hline
\end{tabular}

Table 5 


\begin{tabular}{|c|c|c|c|c|c|c|c|c|}
\hline Stations & Dates & Species & $\begin{array}{c}\mathbf{n} \\
(\mathrm{AChE})\end{array}$ & $\begin{array}{c}\mathbf{n} \\
(\mathbf{L M S})\end{array}$ & $\begin{array}{c}\text { Temperatures } \\
{ }^{\circ} \mathrm{C}\end{array}$ & $\begin{array}{c}\text { Size } \\
\\
\mathrm{mm} \\
(\mathrm{Mean} \pm \mathrm{SE}) \\
\end{array}$ & $\begin{array}{c}\mathbf{A C h E} \\
\mathrm{nmol.min}^{-1} \cdot \mathrm{mgprot}^{-1} \\
\text { (Mean } \pm \mathrm{SE})^{-1} \\
\end{array}$ & $\begin{array}{r}\text { LMS } \\
\text { Min } \\
(\text { Mean } \pm \text { SE) } \\
\end{array}$ \\
\hline Honfleur & 09.2008 & Mytilus sp. & 10 & 10 & 17 & $42 \pm 0.5$ & $43 \pm 15$ & $43 \pm 3$ \\
\hline Le Moulard & 09.2008 & Mytilus sp. & 10 & 10 & 16 & $39 \pm 0.6$ & ND & $39 \pm 0.6$ \\
\hline Honfleur & 09.2009 & Mytilus sp. & 10 & 10 & 15.5 & $43 \pm 1.5$ & $29 \pm 21$ & ND \\
\hline Le Moulard & 09.2009 & Mytilus sp. & 10 & 10 & 16 & $40 \pm 2.5$ & $35 \pm 29$ & ND \\
\hline Wadden sea & 09.2008 & Mytilus sp. & 10 & 25 & 14 & $44 \pm 2.5$ & $70 \pm 57$ & $46 \pm 6$ \\
\hline Cartagena & 09.2008 & $\begin{array}{l}\text { Mytilus } \\
\text { galloprovincialis }\end{array}$ & 10 & 20 & 17 & $45 \pm 10$ & $76 \pm 65$ & $113 \pm 112$ \\
\hline Cape Palos & 09.2008 & $\begin{array}{c}\text { Mytilus } \\
\text { galloprovincialis }\end{array}$ & 10 & 20 & 17 & $45 \pm 10$ & $85 \pm 77$ & $64 \pm 13$ \\
\hline
\end{tabular}

Table 6 


\begin{tabular}{|c|c|c|c|c|c|c|}
\hline Region & Station & Site Code & Site type & Latitude & Longitude & Samples collected \\
\hline English Channel & Seine estuary & $\mathrm{SE}$ & Estuary & $49.260 \mathrm{~N}$ & $0.005 \mathrm{E}$ & Flounder, dab, sediment \\
\hline English Channel & Parfond (Seine Bay) & PAR & Estuary & $49.192 \mathrm{~N}$ & $0.009 \mathrm{~W}$ & Flounder, dab, sediment \\
\hline English Channel & Honfleur (Seine Bay) & HON & Coastal & $49.250 \mathrm{~N}$ & $0.135 \mathrm{E}$ & Mussels \\
\hline English Channel & Le Moulard (Seine Bay) & LM & Coastal & $49.659 \mathrm{~N}$ & $1.233 \mathrm{~W}$ & Mussels \\
\hline English Channel & Villerville (Seine Bay) & VIL & Coastal & $49.242 \mathrm{~N}$ & $0.074 \mathrm{E}$ & Dogwhelk \\
\hline English Channel & Cap de la Hève (Seine Bay) & HEV & Coastal & $49.305 \mathrm{~N}$ & $0.409 \mathrm{E}$ & Dogwhelk \\
\hline English Channel & Pointe de la Loge & LOG & Coastal & $49.424 \mathrm{~N}$ & $1.251 \mathrm{~W}$ & Dogwhelk \\
\hline Iceland & Bjarnarhöfn & BH & Coastal & 65.000 & $22.970 \mathrm{~W}$ & Mussels \\
\hline Iceland & Havassahraun & $\mathrm{HV}$ & Coastal & 64.023 & $22.146 \mathrm{~W}$ & Flounder, mussels \\
\hline Iceland & Iceland 1 & IS1 & Offshore & 63.767 & $16.404 \mathrm{~W}$ & Dab, sediment \\
\hline Iceland & Iceland 2 & IS2 & Offshore & 64.146 & $22.280 \mathrm{~W}$ & Dab, sediment \\
\hline North Sea & Wadden Sea & WS & Coastal & 52.965 & $5.017 \mathrm{E}$ & Mussels, sediment \\
\hline Mediterranean sea & Cartagena & CAR & Coastal & 37.562 & $1.030 \mathrm{~W}$ & Mussels, sediment \\
\hline Mediterranean sea & Cape Palos (marine reserve) & $\mathrm{CP}$ & Coastal & 37.653 & $0.653 \mathrm{~W}$ & Mussels \\
\hline
\end{tabular}

Table 1 


\begin{tabular}{|c|c|c|c|c|c|c|c|c|c|c|c|c|c|c|c|c|c|c|c|c|c|c|c|}
\hline \multirow[t]{4}{*}{ Contaminants } & \multicolumn{3}{|c|}{ Sediment } & \multicolumn{4}{|c|}{ Limanda limanda } & \multicolumn{4}{|c|}{ Platichthys flesus } & \multicolumn{4}{|c|}{ Mytilus sp. } & \multirow[t]{2}{*}{ BAC } & \multirow[t]{2}{*}{ ERL } & \multirow[t]{2}{*}{ BAC } & \multirow[t]{2}{*}{ EAC } & \multirow[t]{2}{*}{ EQS } & \multirow[t]{2}{*}{ BAC } & \multirow[t]{2}{*}{ EQS } & \multirow[t]{2}{*}{ MPC } \\
\hline & \multicolumn{2}{|c|}{ Seine estuary } & Parfond & \multicolumn{2}{|c|}{ Seine estuary } & \multicolumn{2}{|c|}{ Parfond } & \multicolumn{2}{|c|}{ Seine estuary } & Parfond & & Honfleu & & Le Mou & $\operatorname{ard}^{*}$ & & & & & & & & \\
\hline & $\begin{array}{l}49^{\circ} 2 \\
00^{\circ} 0\end{array}$ & $.067 \mathrm{~N}$ & $\begin{array}{l}49^{\circ} 19.021 \mathrm{~N} \\
00^{\circ} 09.072 \mathrm{~W}\end{array}$ & $\begin{array}{l}49^{\circ} 26 \\
00^{\circ} 0\end{array}$ & $\begin{array}{l}.067 \mathrm{~N} \\
.566 \mathrm{E}\end{array}$ & $\begin{array}{r}49^{\circ} 1 \\
000^{\circ}\end{array}$ & $\begin{array}{l}9.021 \mathrm{~N} \\
9.072 \mathrm{~W}\end{array}$ & $\begin{array}{l}49^{\circ} 26 \\
00^{\circ} 00\end{array}$ & $\begin{array}{l}.067 \mathrm{~N} \\
.566 \mathrm{E}\end{array}$ & $\begin{array}{r}49^{\circ} 1 \\
000^{\circ} 0\end{array}$ & $\begin{array}{l}9.021 \mathrm{~N} \\
9.072 \mathrm{~W}\end{array}$ & $\begin{array}{r}49^{\circ} 25 . \\
00^{\circ} 1\end{array}$ & $\begin{array}{l}08 \mathrm{~N} \\
3.59 \mathrm{E}\end{array}$ & $\begin{array}{r}49^{\circ} 65.9 \\
1^{\circ} 23.3\end{array}$ & $\begin{array}{l}7 \mathrm{~N} \\
348 \mathrm{~W}\end{array}$ & & & & & & & & \\
\hline & 2008 & 2009 & $2008 \quad 2009$ & 2008 & 2009 & 2008 & 2009 & 2008 & 2009 & 2008 & 2009 & 2008 & 2009 & 2008 & 2009 & Sedi & ment & & Mytilus sp. & & $\begin{array}{r}\text { Limar } \\
\text { Pla }\end{array}$ & $\begin{array}{l}\text { da limand } \\
\text { ichthys fle }\end{array}$ & $\begin{array}{l}\text { da and } \\
\text { esus }\end{array}$ \\
\hline$\%<20 \mu \mathrm{m}$ & 19.4 & & & & & & & & & & & & & & & & & & & & & & \\
\hline$\%<63 \mu \mathrm{m}$ & 49.0 & & & & & & & & & & & & & & & & & & & & & & \\
\hline$\%$ Total Organic & 1.30 & & 0.18 & & & & & & & & & & & & & & & & & & & & \\
\hline Carbon & & & & & & & & & & & & & & & & & & & & & & & \\
\hline $\operatorname{AL}(\%)$ & 1.79 & & & & & & & & & & & & & & & & & & & & & & \\
\hline $\mathrm{Cd}$ & 0.31 & & & & 0.01 & & TR & & $\mathrm{TR}$ & & $\mathrm{TR}$ & 0.9 & 0.98 & 0.9 & 0.54 & 0.31 & & 0.19 & & & $0.026^{4}$ & & $0.05^{4}$ \\
\hline $\mathrm{Hg}$ & 0.14 & & & & 0.244 & & 0.118 & & 0.326 & & 0.377 & 0.135 & 0.139 & 0.2 & 0.119 & 0.07 & & 0.018 & & 0.02 & $0.035^{4}$ & $0.024^{3}$ & \\
\hline $\mathrm{Pb}$ & 22.1 & & & & 0.04 & & 0.04 & & 0.02 & & 0.02 & 1.73 & 1.77 & 1.4 & 1.16 & 38 & & 0.26 & & & $0.026^{4}$ & & $0.3^{4}$ \\
\hline As & 5.1 & & & & & & & & & & & & & & & 25 & & & & & & & \\
\hline $\mathrm{Cr}$ & & & & & & & & & & & & 0.76 & 0.15 & & 0.45 & 81 & & & & & & & \\
\hline $\mathrm{Cu}$ & 9.6 & & & & 0.99 & & 0.89 & & 0.75 & & 0.93 & 6.10 & 5.4 & & 5.20 & 27 & & & & & & & \\
\hline $\mathrm{Ni}$ & & & & & 0.28 & & 0.17 & & 0.25 & & 0.08 & 2.42 & 0.5 & & 0.87 & 36 & & & & & & & \\
\hline $\mathrm{Zn}$ & 54.9 & & & & 23.2 & & 16.2 & & 17.4 & & 19.5 & & 55.0 & & 61.0 & 122 & & & & & & & \\
\hline Phenanthrene & 10.4 & & 3.7 & & & & & & & & & 8.90 & 8.5 & 6.2 & 8.5 & 32 & & 2.2 & 340 & & & & \\
\hline Anthracene & 3.4 & & $<0.1$ & & & & & & & & & 1.7 & 1.9 & & & 5 & & & 58 & & & & \\
\hline Fluoranthene & 23.3 & & 4.7 & & & & & & & & & 25.4 & 19.2 & 5.7 & 5.9 & 39 & & 2.44 & & & & & \\
\hline Pyrene & 19.4 & & 3.8 & & & & & & & & & 31.8 & 19.6 & 6.8 & 10.7 & 24 & & 1.8 & 20 & & & & \\
\hline Benz[a]anthracene & 10.6 & & 2.5 & & & & & & & & & 19.5 & 13.2 & 1.2 & 2.1 & 16 & & 16 & 16 & & & & \\
\hline Chrysene/Triphenylene & 14.6 & & 6.2 & & & & & & & & & 30.3 & 20.4 & 3.1 & 3.3 & 20 & & & & & & & \\
\hline Benzo[k]fluoranthene & 38.3 & & 8.9 & & & & & & & & & & & & & & & & 52 & & & & \\
\hline Benz[a]pyrene & 14.5 & & 2.6 & & & & & & & & & 11.7 & 7.8 & & 2.1 & 30 & & 0.28 & & & & & \\
\hline Benz[g,h,i]perylene & 11.7 & & & & & & & & & & & 16.1 & 13.8 & & & 80 & & 0.5 & 22 & & & & \\
\hline Indeno[1,2,3-cd]pyrene & 13.5 & & 5.2 & & & & & & & & & 9.3 & 1.86 & 0.4 & & 103 & & 0.48 & 110 & & & & \\
\hline CB28 & & & & & & & & & & & & & & & & & & & & & & & \\
\hline CB52 & & & & $1.51^{1}$ & $1.60^{2}$ & & $0.89^{2}$ & $2.27^{1}$ & $0.78^{2}$ & & $0.66^{2}$ & 5.2 & 1.7 & 21.71 & 0.3 & 0.22 & & 0.15 & 0.64 & & $0.15^{5}$ & & \\
\hline CB101 & & & & $6.54^{1}$ & $8.15^{2}$ & & $3.29^{2}$ & $13.00^{1}$ & $3.65^{2}$ & & $2.91^{2}$ & 31.8 & 17.3 & 3.6 & 26.3 & 0.12 & & 0.15 & 1.08 & & $0.15^{5}$ & & 75 \\
\hline CB105 & & & & $21.34^{1}$ & $22.42^{2}$ & & $9.15^{2}$ & $43.37^{1}$ & $8.19^{2}$ & & $7.69^{2}$ & 103 & 66.1 & 2.1 & 1 & 0.14 & & 0.14 & 1.2 & & $0.14^{5}$ & & \\
\hline CB118 & & & & $4.47^{1}$ & $3.03^{2}$ & & $1.71^{2}$ & $8.04^{1}$ & $1.37^{2}$ & & $1.11^{2}$ & 15.9 & 3.8 & 4.2 & 0.2 & & & 0.12 & & & & & \\
\hline CB138 & & & & $2.34^{1}$ & $17.44^{2}$ & & $9.49^{2}$ & $42.4^{1}$ & $7.79^{2}$ & & $5.97^{2}$ & 64 & 40 & 3.8 & 0.8 & 0.17 & 11.5 & 0.12 & 0.24 & & $0.12^{5}$ & & \\
\hline CB153 & & & & $37.03^{1}$ & $38.34^{2}$ & & $18.44^{2}$ & $66.69^{1}$ & $14.712^{2}$ & & $14.99^{2}$ & 88 & 94.2 & 9 & 0.9 & 0.15 & & 0.12 & 3.16 & & $0.12^{5}$ & & \\
\hline CB156 & & & & $78.75^{1}$ & $44.29^{2}$ & & $21.33^{2}$ & $145.39^{1}$ & $17.80^{2}$ & & $18.38^{2}$ & 184 & 158 & 3 & 1.9 & 0.19 & & 0.12 & 16 & & $0.12^{5}$ & & \\
\hline CB180 & & & & $2.31^{1}$ & $1.55^{2}$ & & $0.48^{2}$ & $4.35^{1}$ & $0.62^{2}$ & & $0.69^{2}$ & & 1.9 & 6 & & & & & & & $0.08^{5}$ & & \\
\hline & & & & $15.15^{1}$ & $11.09^{2}$ & & $2.38^{2}$ & $44.70^{1}$ & $2.13^{2}$ & & $3.57^{2}$ & 8.4 & 2.9 & 80.26 & & 0.12 & & 0.12 & 4.8 & & $0.12^{5}$ & & \\
\hline
\end{tabular}

Table 4 


\begin{tabular}{|c|c|c|c|c|c|c|c|c|c|c|c|c|c|}
\hline \multirow[t]{2}{*}{ Stations } & \multirow[t]{2}{*}{ Dates } & \multirow[t]{2}{*}{$\begin{array}{l}\text { Assessment } \\
\text { criteria }\end{array}$} & \multicolumn{3}{|c|}{$\begin{array}{c}\text { Larval abnormalities in } \\
\text { Crassostrea gigas } \\
\end{array}$} & \multicolumn{3}{|c|}{ Corophium arenarium } & \multicolumn{2}{|c|}{ DR-Calux } & \multicolumn{3}{|c|}{ Sediment } \\
\hline & & & $\mathrm{CE}_{50(\mathrm{~g} / \mathrm{L})}$ & $\begin{array}{l}\text { Confidence } \\
\text { interval 95\% } \\
\text { g sediment } \\
\text { dry wt/L }\end{array}$ & $\begin{array}{l}\text { \% net of } \\
\text { larval } \\
\text { abnormalities } \\
5 \mathrm{~g} / \mathrm{L}\end{array}$ & $\mathrm{CE}_{50}(\%)$ & $\mathrm{CE}_{20}(\%)$ & $\begin{array}{l}\% \\
\text { Corophium } \\
\text { net died in } \\
\text { the not } \\
\text { diluted } \\
\text { sediment }\end{array}$ & $\begin{array}{l}\text { DR Calux pg } \\
\text { TEQg }{ }^{-1} \text { Dry. } \\
\text { wt }\end{array}$ & $\begin{array}{l}\text { Cytotoxicity } \\
\text { at the } \\
\text { highest } \\
\text { concentration }\end{array}$ & $\%$ TOC & $\%<20 \mu \mathrm{m}$ & $\%<63 \mu \mathrm{m}$ \\
\hline $\begin{array}{l}\text { Seine estuary } \\
\text { France }\end{array}$ & 19.09 .2008 & & 5.2 & $4>\mathrm{CE} 50>7,3$ & 53.9 & $>100$ & $>100$ & 4.4 & $1900 \pm 707$ & Yes & 1.3 & 19.4 & 49.0 \\
\hline $\begin{array}{l}\text { Seine estuary } \\
\text { France }\end{array}$ & 23.09.2009 & & & & & & & & $\begin{array}{c}3050 \pm \\
1626\end{array}$ & Yes & & & \\
\hline $\begin{array}{l}\text { Cartagena } \\
\text { Spain }\end{array}$ & 23.10 .2008 & & $>10$ & ND & 33.6 & $>100$ & $>100$ & 10.7 & & & 0.87 & 33.7 & 59.2 \\
\hline $\begin{array}{l}\text { Wadden Sea } \\
\text { Netherland }\end{array}$ & 19.09 .2008 & & 1.1 & $\begin{array}{c}0,95 \\
<\mathrm{CE} 50<1,21\end{array}$ & 98.9 & $>100$ & $>100$ & 12.4 & & & 2.90 & 24.5 & 64.0 \\
\hline IS2 Offshore & 26.11 .2009 & & $>10$ & ND & 5.4 & $>100$ & $>100$ & 5.5 & $<\mathrm{LQ}$ & Yes & $0 / 78$ & 6.9 & 12.8 \\
\hline & & BAC & & & 20 & & & 30 & 10 & & & & \\
\hline & & EAC & & & 50 & & & 60 & 40 & & & & \\
\hline
\end{tabular}

Table 2 


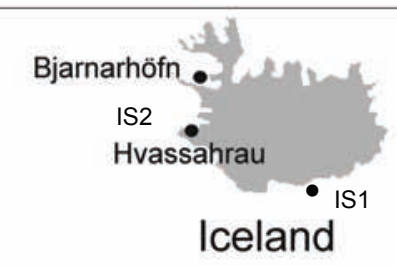




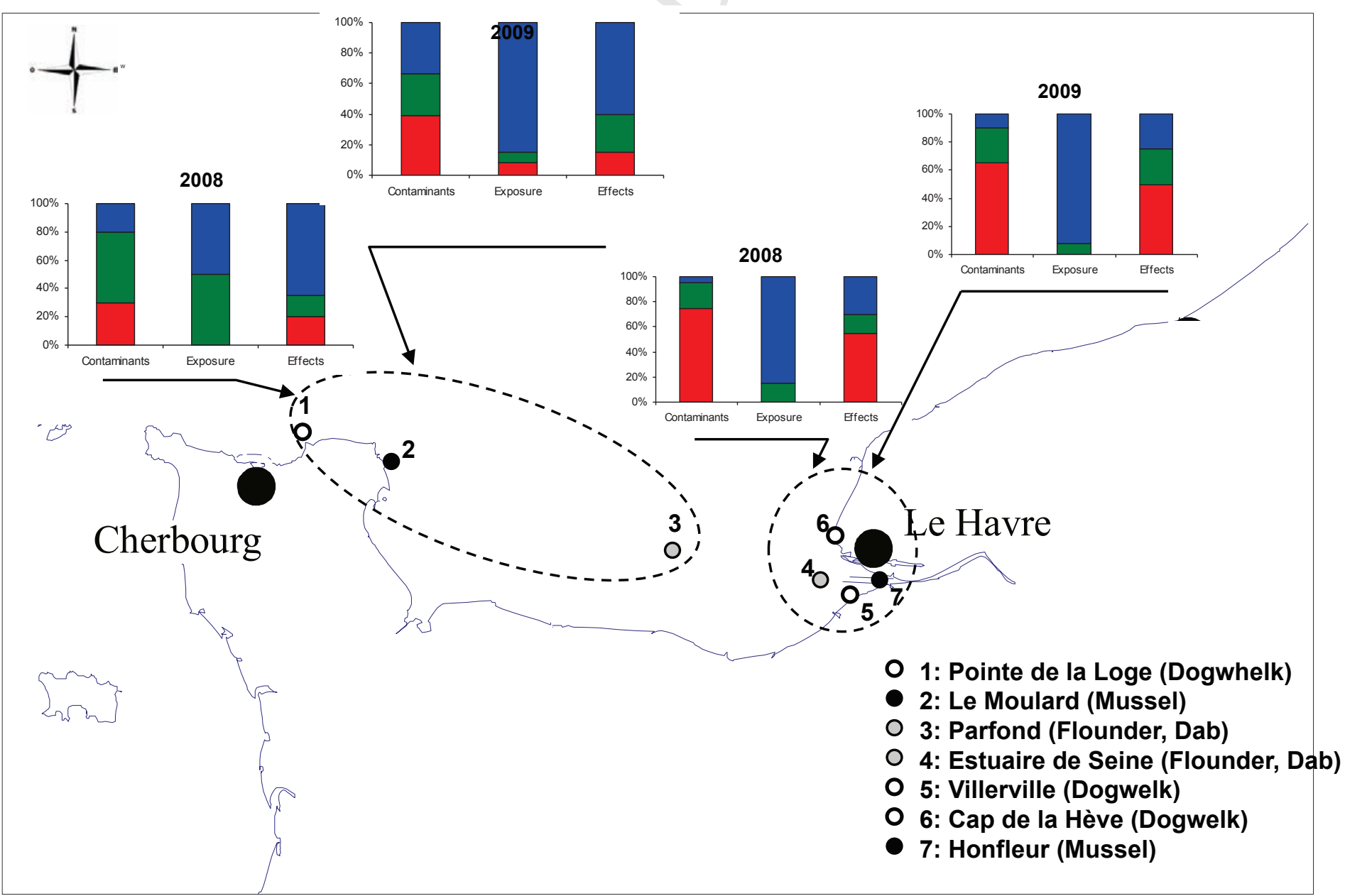

